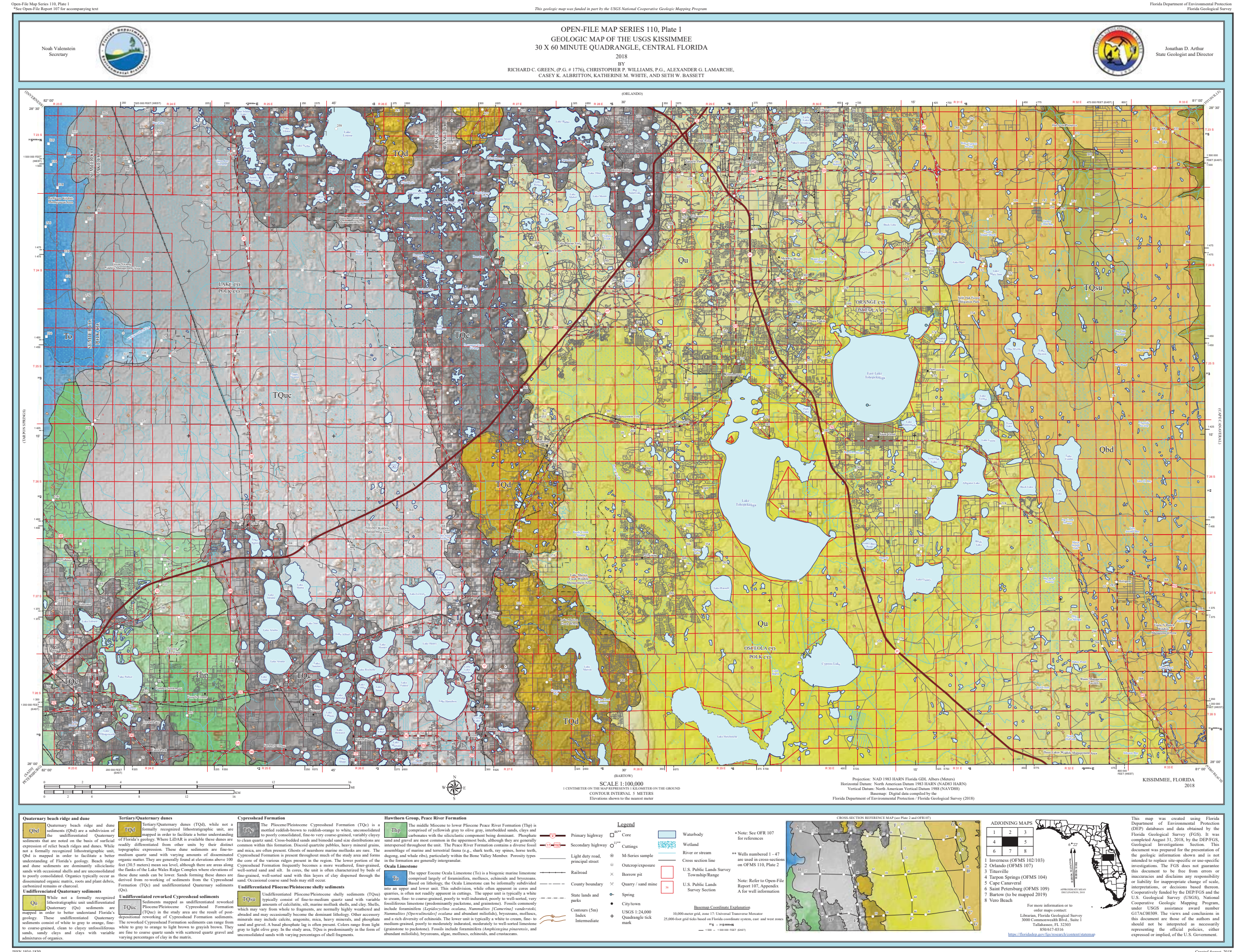




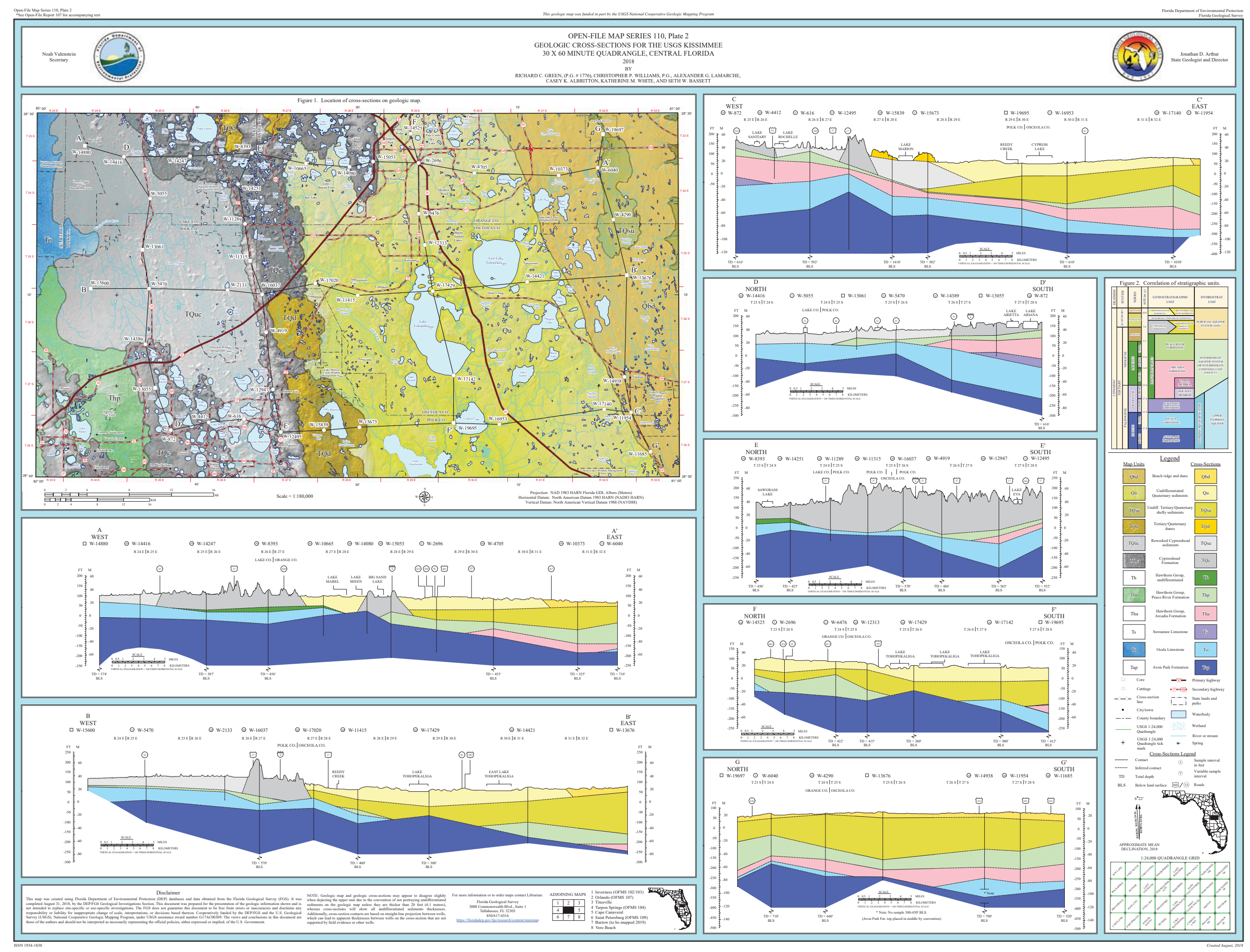




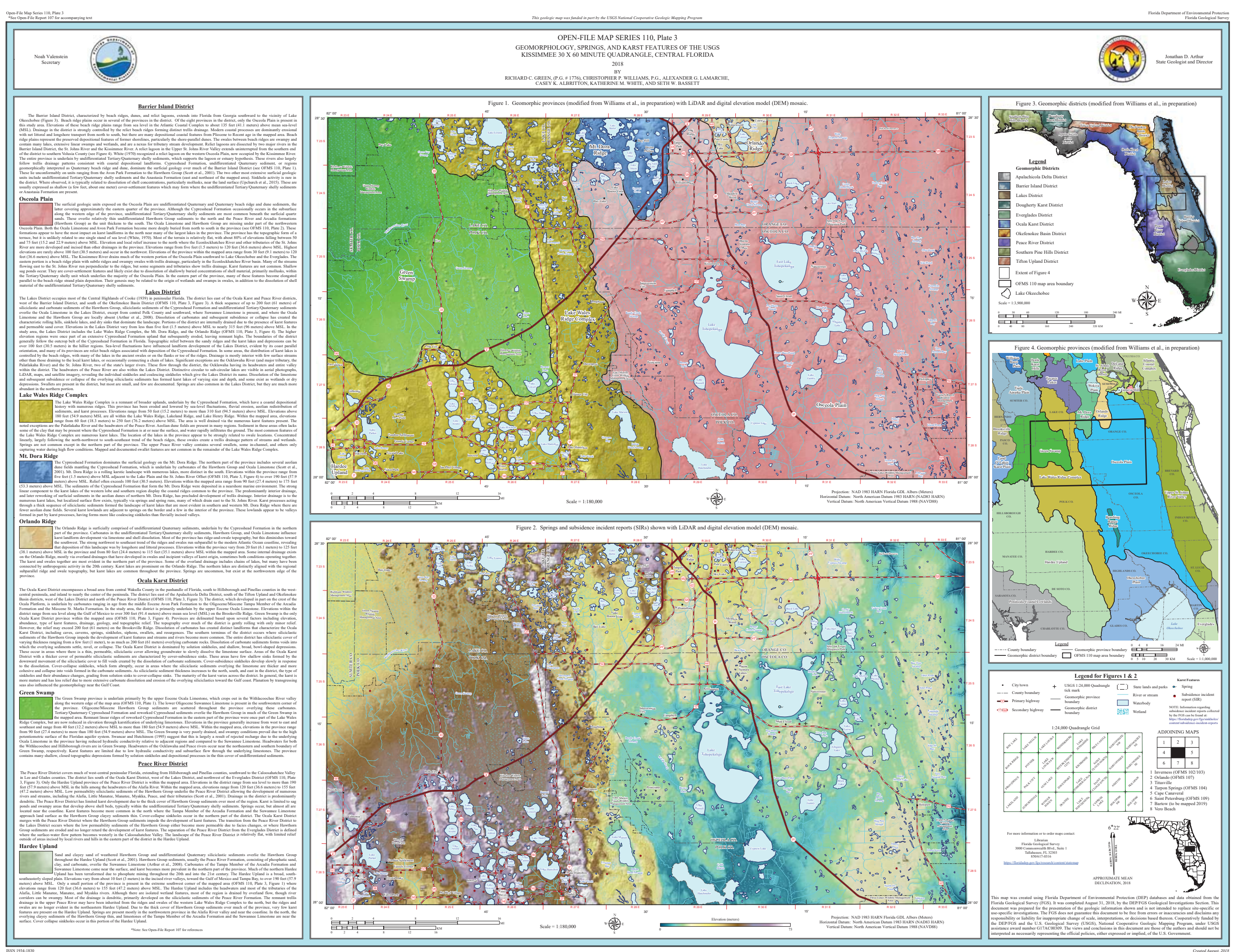




\section{STATE OF FLORIDA}

\section{DEPARTMENT OF ENVIRONMENTAL PROTECTION}

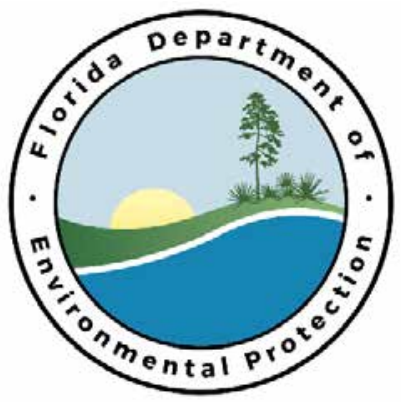

FLORIDA GEOLOGICAL SURVEY

Jonathan D. Arthur, State Geologist and Director

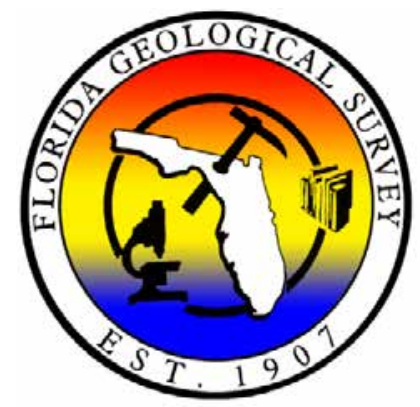

OPEN-FILE REPORT 107

Text to accompany geologic map of the USGS Kissimmee 30 x 60 minute quadrangle, central Florida

(Open-File Map Series 110)

By

Richard C. Green, (P.G. \# 1776), Christopher P. Williams, P.G., Alexander G. Lamarche, Casey K. Albritton, Katherine M. White, and Seth W. Bassett

2018

ISSN 1058-1391

This study was funded in part by the USGS National Cooperative Geologic Mapping Program under assistance award number G17AC00309 in Federal fiscal year 2017 



\section{TABLE OF CONTENTS}

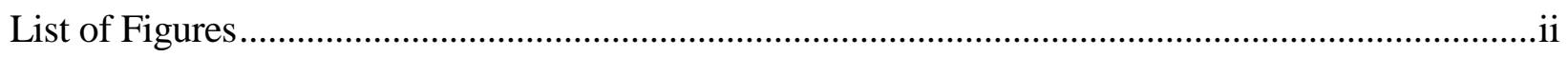

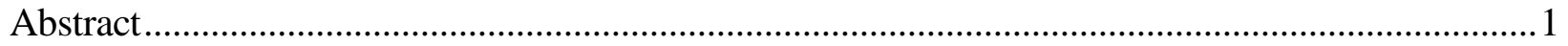

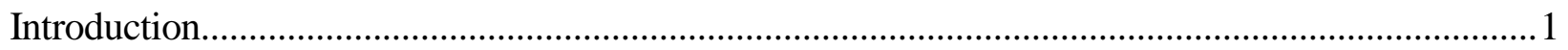

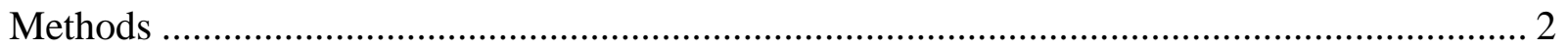

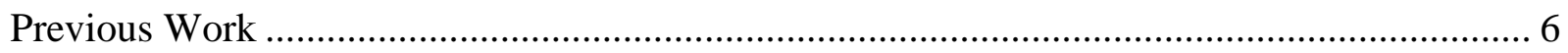

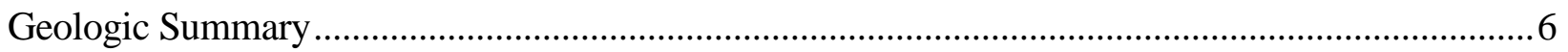

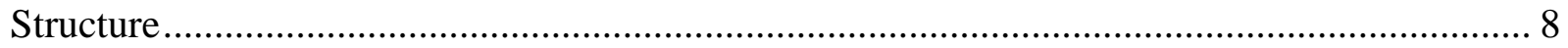

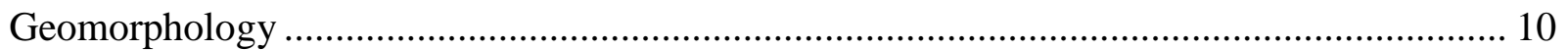

Barrier Island District ............................................................................................ 10

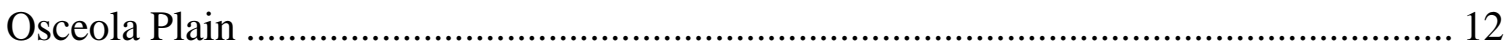

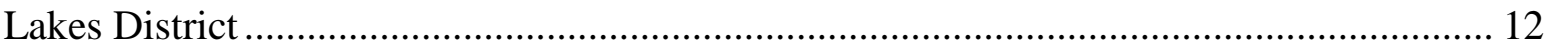

Lake Wales Ridge Complex ……………………………...................................... 13

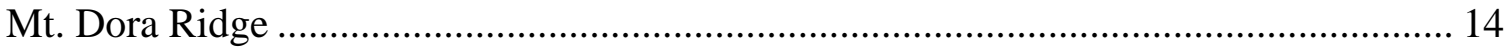

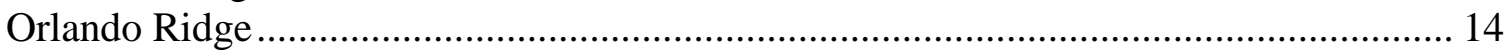

Ocala Karst District...................................................................................................... 15

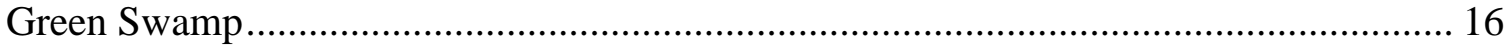

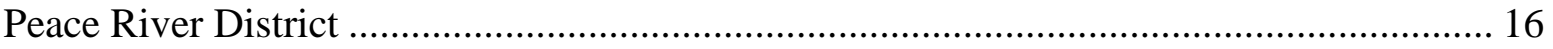

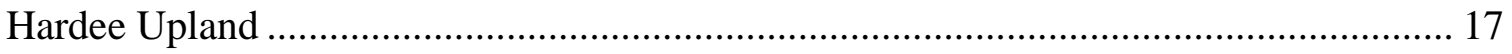

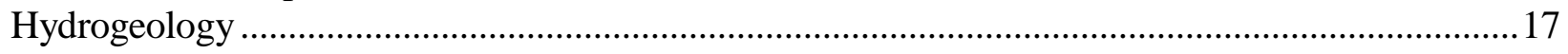

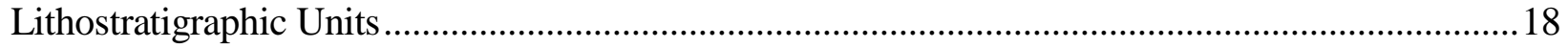

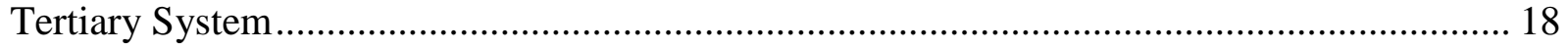

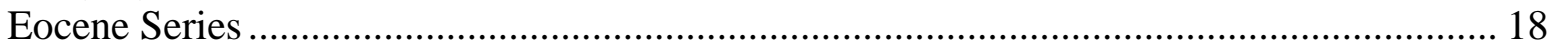

Avon Park Formation................................................................................................18

Ocala Limestone ………..............................................................................19

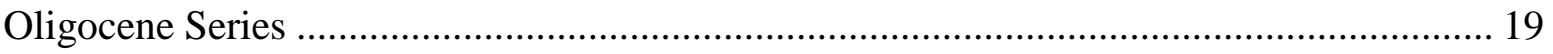

Suwannee Limestone ………………………………............................................ 19

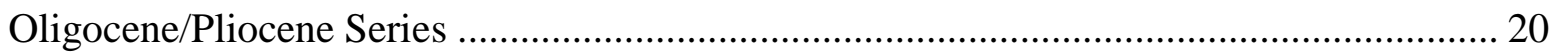

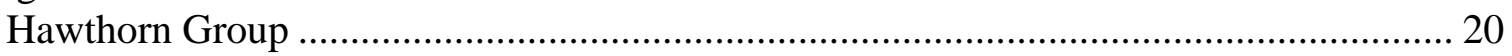

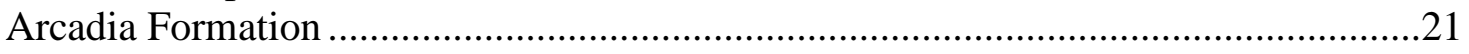

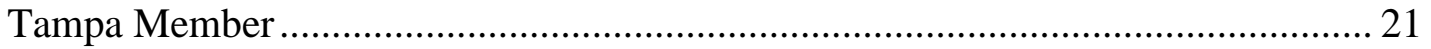

Peace River Formation..........................................................................................22

Bone Valley Member .............................................................................................. 23

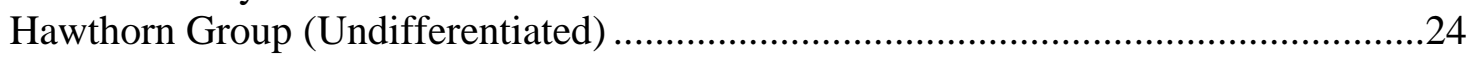

Tertiary/Quaternary Systems ………………………………............................................. 25

Pliocene/Pleistocene Series................................................................................................... 25

Cypresshead Formation ........................................................................................25

Undifferentiated reworked Cypresshead Formation........................................................26

Pliocene/Pleistocene shelly sediments .....................................................................26

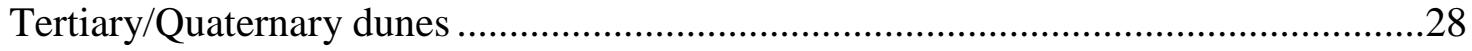

Pleistocene to Holocene Series ………………………..................................................... 28

Undifferentiated Quaternary sediments ..................................................................28

Quaternary beach ridge and dune ..........................................................................28

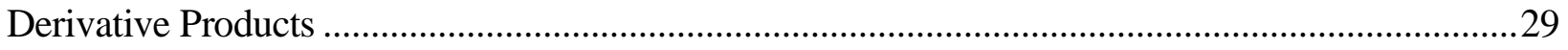

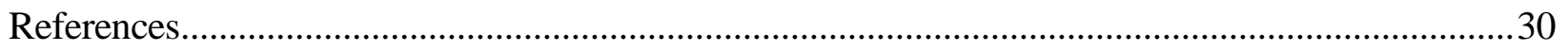

Acknowledgements …………………………………………………………………………....

Appendix A: Florida Geological Survey Wells Utilized for Study ......................................................36 


\section{LIST OF FIGURES}

Figure 1. Nearby areas mapped by the FGS STATEMAP Program. ........................................ 2

Figure 2. Borehole data points, outcrops, and surface samples utilized for geologic models........ 3

Figure 3. Boxplot of top of lithostratigraphic unit elevation ranges.......................................... 5

Figure 4. Location of river basins, springs, and other water bodies. ........................................ 7

Figure 5. Principal subsurface structures of North Florida ................................................ 9

Figure 6. Geomorphic Provinces in the study area ........................................................ 11

Figure 7. Phosphate mining areas with extents of Bone Valley Member ................................. 24 


\title{
Text to accompany geologic map of the USGS Kissimmee 30 x 60 minute quadrangle, central Florida (Open-File Map Series 110)
}

\author{
Richard C. Green, (P.G. \# 1776), Christopher P. Williams, P.G., Alexander G. Lamarche, Casey \\ K. Albritton, Katherine M. White, and Seth W. Bassett
}

\begin{abstract}
The accompanying 1:100,000 scale geologic map (Open-File Map Series 110, Plate 1) depicts the areal distribution of bedrock and surficial geologic units for the U.S. Geological Survey (USGS) Kissimmee 30 × 60 minute quadrangle. The map was constructed using a combination of field mapping (at 1:24,000 scale), compilation of data from existing maps (various scales), core and cuttings analyses and descriptions, and analyses of various Geographic Information System (GIS) data sources. The resulting data were compiled in ESRI ${ }^{\circledR}$ ArcGIS $^{\circledR}$ ArcMap $^{\text {TM }}$ 10.3.1 software for publication as part of the Florida Geological Survey Open-File Map Series. Mapped units range in age from Eocene to Quaternary. Important resources in the mapped area include potable groundwater, springs, phosphate, sand, and clay. The geologic maps produced for this area not only provide a greater understanding of the interaction between the geologic units, associated aquifers, karst, springs, and ecosystems, but also have utility as a land management tool for economic development, mineral and energy production, and environmental protection for Florida. Examples include designing new construction projects, siting new water supply wells, energy production facilities, waste management and storage facilities, locating sources of mineable mineral resources, and protection of springs, surface, and groundwater quality.
\end{abstract}

Keywords: Florida, geologic map, Avon Park Formation, Ocala Limestone, Arcadia Formation, Peace River Formation, Hawthorn Group, Cypresshead Formation, geomorphology, hydrogeology, karst, sinkholes, Green Swamp, Floridan aquifer system, Lake County, Orange County, Osceola County, Polk County, Sumter County, Kissimmee.

\section{INTRODUCTION}

Florida Geological Survey (FGS) Open-File Report (OFR) 107 accompanies Open-File Map Series (OFMS) 110, which is comprised of three plates. Plate 1 depicts the near-surface geology of the USGS Kissimmee 30 x 60 minute quadrangle on a digital elevation model (DEM). Plate 2 depicts seven geologic cross-sections, a stratigraphic correlation chart, and a geologic map with cross-section lines for the study area. Plate 3 is a geomorphology map, along with a DEM, showing locations of known springs and subsidence incident reports.

The study area is located in central Florida (Figure 1) in portions of Lake, Orange, Osceola, Polk, and Sumter counties. It includes the communities of Auburndale, Bay Lake, Davenport, Edgewood, Haines City, Kissimmee, Lake Buena Vista, Lakeland, Saint Cloud, and Winter Haven. The quadrangle is bounded to the west by the USGS Tarpon Springs 30 x 60 minute quadrangle, (Green et al., 2012a; Green et al., 2012b), to the northwest by the USGS Inverness 30 x 60 minute quadrangle (Green et al., 2011; Williams et al., 2011; Williams et al., 2012; Williams and Green, 2012), to the north by the USGS Orlando 30 x 60 minute quadrangle (Green et al., 2015a; Green et al., 2015b), and to the southwest by the USGS St. Petersburg 30 x 60 minute quadrangle (Green et al., 2017a; Green et al., 2017b), previously mapped under the STATEMAP program. It is 
bounded to the south by the USGS Bartow $30 \times 60$ minute quadrangle (Figure 1). The Econlockhatchee, Kissimmee, and Withlacoochee rivers, along with numerous creeks and lakes, occur in the map area. Recharge to and discharge from the Floridan aquifer system (FAS) occurs throughout the study area. The FAS is the primary source of water for springs and drinking water in the region.

One objective for this report is to provide basic geologic information for the accompanying OFMS 110. Information provided by this report and the plates in OFMS 110 is intended for a diverse audience of professionals in geology, hydrology, engineering, environmental and urban planning, and laypersons, all of whom have varying levels of geologic knowledge. The maps can help users identify and interpret geologic features which impact activities related to groundwater quality and quantity, as well as aid in locating mineral resources, land-use planning, and construction project design. Applied uses of the maps and data in this report include: 1) identifying potential new mineral resources, 2) characterizing zones of geologic hazards and potential aquifer recharge and confinement, 3) aiding water-management decisions on groundwater usage, 4) providing information on aquifer vulnerability to potential pollution, 5) ecosystem, wetlands, and environmental characterization, and 6) recreational uses.

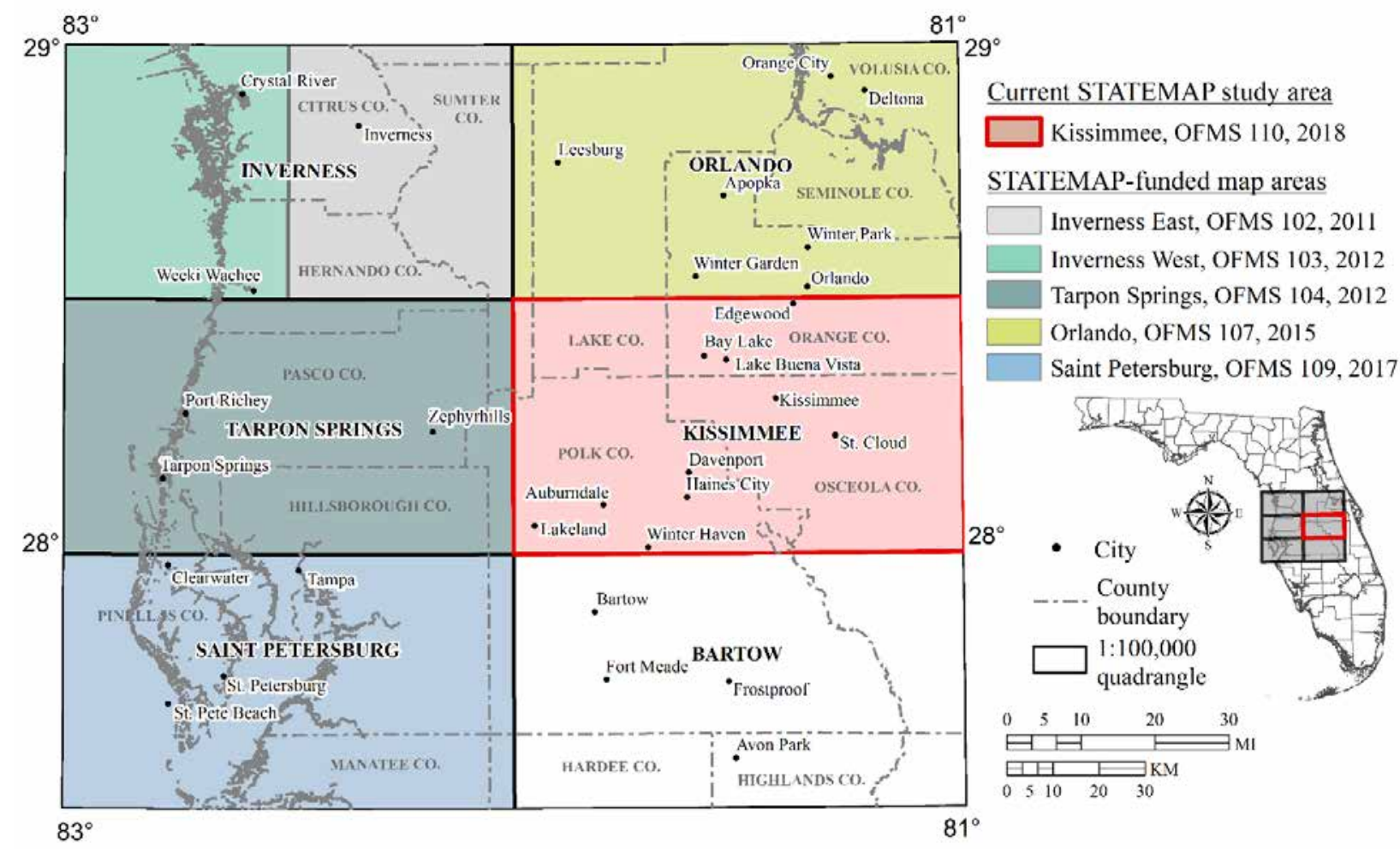

Figure 1. Nearby areas mapped by the FGS STATEMAP Program.

\section{Methods}

Mapping efforts consisted of: 1) reviewing and compiling existing geologic literature and data, 2) mapping geologic units in the field at 1:24,000 scale, 3) analyses of existing cores, cuttings, and outcrop samples from the Florida Geological Survey sample repository, 4) new core drilling, 5) collecting and describing outcrop samples, and 6) preparing a geologic map, geologic cross-sections, and a geomorphic map of the area. Fieldwork, performed during the fall of 2017 
through the summer of 2018, consisted of sampling and describing numerous outcrops and borrow pit exposures.

Fifteen new samples of geologic material were added to the FGS surface-sample collection (M-Series) and two cores (762 feet or 223.3 meters total) were drilled for the project. Several dozen outcrops and exposures were also examined during the project. In addition to new cores collected for this study, approximately 380 sets of cores and cuttings archived in the Florida Geological Survey sample repository were examined and formation picks were made for mapped geologic units. Over 7,600 formation picks derived from prior mapping data in adjacent areas, in addition to data from cores and cuttings within the current area, were utilized in developing various modeled surfaces. Figure 2 shows the locations of FGS cores and cuttings data points, outcrops, and collected surface samples within the study area. Appendix A includes FGS wells with core and/or cuttings samples within the mapped area which were examined by the authors and used for the top of rock model or for determining the surface and subsurface geologic formations. An interpolated top of rock surface was developed using kriging along with a Digital Elevation Model (DEM) to generate an overburden thickness model. The map and accompanying plates were developed in ESRI $^{\circledR}$ ArcGIS $^{\circledR}$ ArcMap $^{\text {TM }}$ 10.3.1 software for publication as part of OFMS 110.

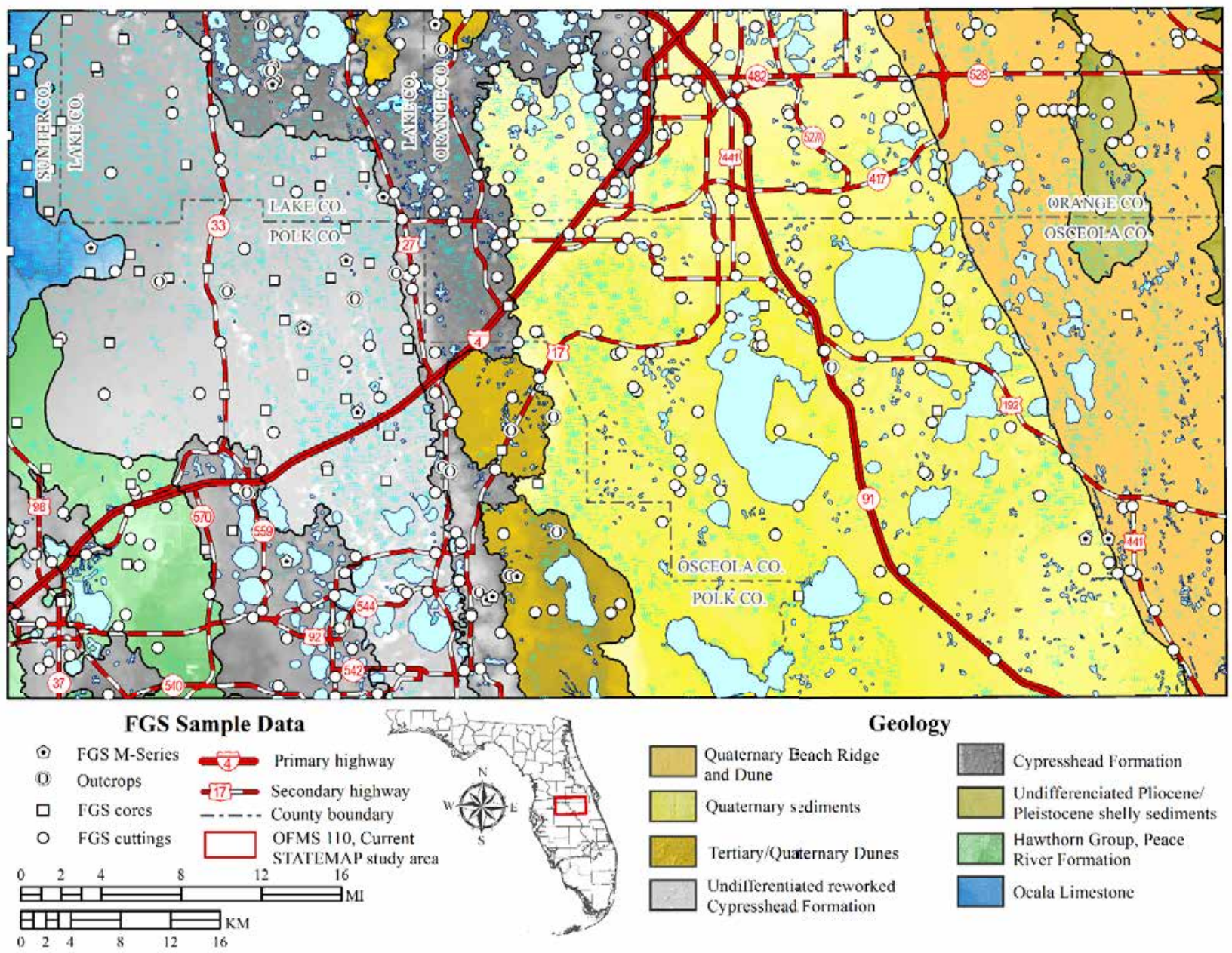

Figure 2. Borehole data points, outcrops, and surface samples utilized for geologic models. 
Due to incomplete light detection and ranging (LiDAR) coverage in the study area, a custom elevation model was created for this study area. Two datasets were used to create this elevation model: standard LiDAR elevation models with horizontal resolutions ranging from one foot ( 0.3 meters) to 31 feet (10 meters), and an elevation model based from topographic contours with a horizontal resolution of 100 feet (30.5 meters). LiDAR coverage currently exists for the entirety of Sumter, Polk, Osceola, and Orange counties; however, the only coverage available for the majority of Lake County was from a previously mosaiced LiDAR dataset.

The hybrid elevation model was created by first combining all of the existing LiDAR elevation models into a single raster (a matrix of cells [pixels] organized into a grid where each cell [pixel] contains a value representing an elevation). The lower resolution contour-based DEM was re-sampled and aligned to match the higher resolution LiDAR elevation models. A conditional statement was then used in ArcGIS to create a new hybrid raster by selecting an elevation value from the LiDAR grid if available; where LiDAR was not available, elevation values were drawn from the lower resolution, contour-based DEM.

Top of unit rasters were created for the major geologic units within the study area using the borehole descriptions produced during the course of this study. In order to produce interpolated top of unit rasters, the borehole depth for the top of each unit was first converted from depths below land surface into elevations referenced to mean sea level. This conversion was performed by taking the elevation value of the well point from the digital elevation model raster and subtracting the depth value.

Prior to modeling, the elevation values for each geologic unit were used to create a Natural Neighbor (NN) interpolation of the top of unit surface. The NN method of interpolation is a simple and exact interpolation method that relies on Voronoi tessellation (a partitioning of a plane into regions based on distances to points) to select a local subset of points and determine a weighted influence at every raster grid cell. The NN method produces a surface that passes through every data point in the input data set and thus does not attempt to account for error or outliers in the manner of kriging. This method is particularly useful for visualizing the 'raw' data for problematic areas and extreme outliers prior to building and optimizing a kriged model.

The final interpolation of the top of unit rasters was performed using ArcMap's Geostatistical Analyst extension. All surface models were created using the Simple Kriging method or the Empirical Baysian Kriging method. Regardless of the kriging method used, substantial attention was devoted to manually tuning each model to ensure a good fit to the empirical semivariogram of each dataset. All units exhibited non-normal distributions and significant spatial trends within the study area. In order to correct for this, the data were first adjusted using the normal score method, and then detrended using the first, second, or third polynomial detrend functions prior to modeling. Model parameters - primarily the kernel type, lag distance, and number of lags - were manually adjusted for each unit to ensure goodness of fit of the model to the data and to produce models with a suitably low error. Lag size was empirically calculated based on the total spatial extent of the combined datasets, and adjusted slightly to improve model performance.

After examining the initial models created for each unit, it was evident that some of the predictive errors in the first kriging models were directly attributable to either low data density, a handful of local outliers in the borehole data, or both. Outliers are a common occurrence in Florida geologic data for a variety of reasons both human and natural, including: 1) Hawthorn Group units can be difficult to distinguish even for a trained professional geologist, and therefore some degree of uncertainty always exists in locating contacts, 2) many of the borehole samples are based on 
cuttings taken at intervals of 10 feet (3.1 meters), which introduces uncertainty in the elevation of the contacts even when the contact is clearly evident, and 3) the presence of karst in limestone units can produce significantly different unit elevations in boreholes a short distance apart. In cases where the accuracy metrics of the modeled surfaces indicated large amounts of error due to a handful of extreme outliers, an iterative modelling process was used to reduce the average standard error of the interpolated surface and the least accurate boreholes were removed from the dataset via cross-validation to improve predictive accuracy. After the removal of problematic data points - generally fewer than 5 boreholes per unit - a new interpolated surface was generated.

Figure 3 is a boxplot used to illustrate the distribution and range of elevation values where each mapped unit was found within the study area, relative to mean sea level (MSL). The crossbar within the box represents the median elevation value for each geologic unit. The upper and lower borders of each box correspond to the $25^{\text {th }}$ and $75^{\text {th }}$ percentiles, or the first and third quartiles, respectively; this area is also called the interquartile range and represents the middle $50 \%$ of the values in each group. The whiskers that extend from each boxplot reach no further than $150 \%$ of the interquartile range. Data that fall beyond the whiskers are considered outlier points and are represented by a dot.

Once the top of unit models were completed, they were exported to floating point rasters whose cell size and borders were snapped to the hybrid digital elevation model. These interpolated surfaces were then subtracted from the elevation model to produce a raster showing overburden depth between each unit and land surface. The overburden rasters were then used to assist in drawing the final surficial geologic map for the study area.

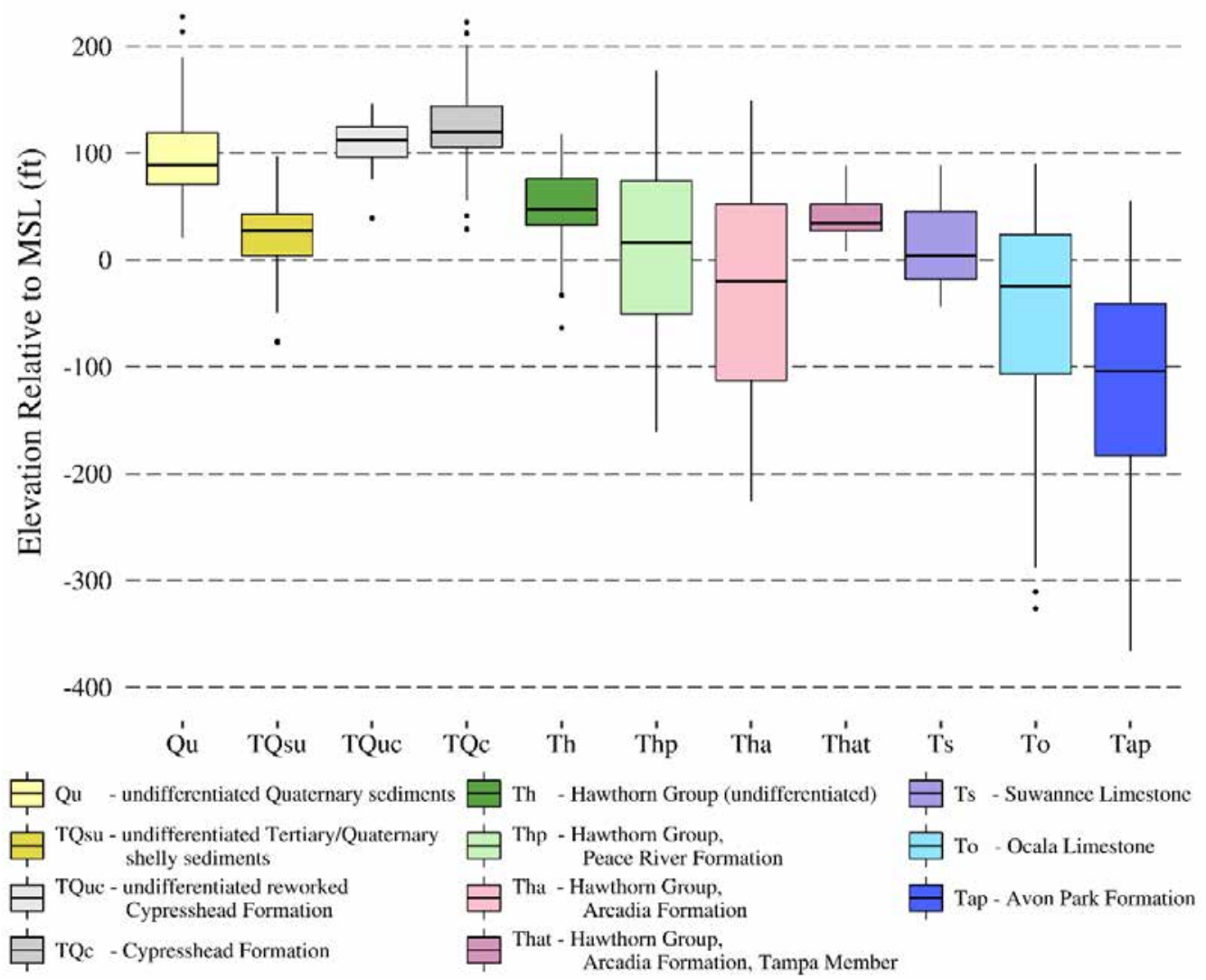

Figure 3. Boxplot of top of lithostratigraphic unit elevation ranges. 
Much of the study area is blanketed by a veneer of undifferentiated Tertiary and Quaternary sediments. For this reason, and in keeping with geologic mapping practices developed by Scott et al. (2001), the authors have adopted the policy of mapping the first named geologic unit within 20 feet (6.1 meters) of the surface. If undifferentiated Quaternary (Qu) sediments attain a thickness greater than 20 feet (6.1 meters), then they appear as the mapped unit. If these undifferentiated sediments are less than 20 feet (6.1 meters) thick, then the underlying lithostratigraphic unit appears on the map. It is noted that the geologic map (OFMS 110, Plate 1) and geologic crosssections (OFMS 110, Plate 2) may appear to disagree slightly when depicting the upper unit due to this convention. This is due to the fact that geologic cross-section contacts are based on straightline projection between wells and, thus, may lead to apparent thicknesses of units between wells that are not supported by field evidence or other wells nearby.

Parts of the region are heavily vegetated, and access to several large sections of the mapped area was hindered by the presence of wetlands, farms, ranches, and other privately-owned land. Additionally, parts of the area are developed with subdivisions, many of which are gated communities. In such instances, the authors had to rely on existing well and core data. Fieldwork access was typically limited to public roads, State-owned, and county-owned lands.

\section{Previous Work}

The current study builds on many previous geologic investigations in and around the present map area which were useful in preparing this report. Preliminary county geologic maps for Lake (Scott, 1992), Orange (Scott, 1993a), Osceola (Scott, 1993b), Polk (Campbell, 1993b), and Sumter (Campbell, 1993a) counties were published by the FGS at 1:126,720 scale. However, each of these geologic maps were constructed in an average time-frame of two to four weeks utilizing selected in-house geologic data with minimal field work. Although they provided a starting point for mapping undertaken for this project, significant refinement of prior geologic maps was possible as a result of this project. A statewide geologic map (Scott et al., 2001) also provided a framework for the current, more detailed mapping.

Scott (1988) published detailed descriptions, structure contour maps, and isopach maps for units of the Hawthorn Group. Huddlestun (1988) defined and discussed the Cypresshead Formation. This study also benefitted from the work performed during geologic mapping of the USGS Orlando 30 x 60 minute quadrangle (Green et al., 2015a; Green et al., 2015b), the USGS Tarpon Springs 30 x 60 minute quadrangle (Green et al, 2012a; Green et al., 2012b), and the USGS St. Petersburg 30 x 60 minute quadrangle (Green et al, 2017a; Green et al., 2017b). Some of the field relationships and stratigraphic problems were worked out during those projects and data gathered proved invaluable to the completion of this project.

\section{GEOLOGIC SUMMARY}

The near surface geology of the USGS 30 x 60 minute Kissimmee quadrangle is composed of a complex mixture of middle Eocene to Quaternary carbonate and siliciclastic sediments. A combination of factors, including fluvio-deltaic deposition, marine deposition, dissolution of underlying carbonates (karstification), erosion of sediments as a result of eustatic changes in sea level, and structural features have influenced the geology of the study area.

The oldest unit to crop-out in the Kissimmee quadrangle is the Eocene Ocala Limestone (To). This unit is exposed in the vicinity of the Withlacoochee River (see OFMS 110, Plate 1). Detailed description of the lithology of all units found in the study area begins on page 18 of this 
publication. Along with lithologic descriptions, several diagnostic foraminifera aid in distinguishing Ocala Limestone from the Avon Park Formation. The Avon Park Formation contains Cushmania [Dictyoconus] americana, Discorinopsis gunteri, Lituonella floridana, Cribrobulimina (Valvulina) cushmani, Fabiana cubensis, and Spirolina coryensis which are not found in the Ocala Limestone. The occurrence of Nummulites ocalanus, Lepidocyclina ocalana, and Amphistegina pinarensis cosdeni in the Ocala Limestone also helps to distinguish it from the Avon Park Formation in the mapped area.

Much of the Kissimmee quadrangle is located within the Kissimmee, Withlacoochee (south), Ocklawaha, Upper St. Johns, and Peace River basins, along with small portions of the Hillsborough River basin in the southwestern map area (Figure 4).

Portions of the recharge areas for many of the springs and karst lakes in the region are located within and adjacent to the study area. Many of the springs in the region have shown significant increases in pollutants in the last few decades, particularly nitrate (Scott et al., 2002; Copeland et al., 2011). Detailed geologic mapping of lithostratigraphic units in this area provides critical data needed for future assessments of vulnerability of aquifer systems and springs to contamination. Understanding the surficial geology of the mapped area is a key factor in developing management and protection plans, not only for the springs, but for the unconfined portions of the Floridan aquifer system.

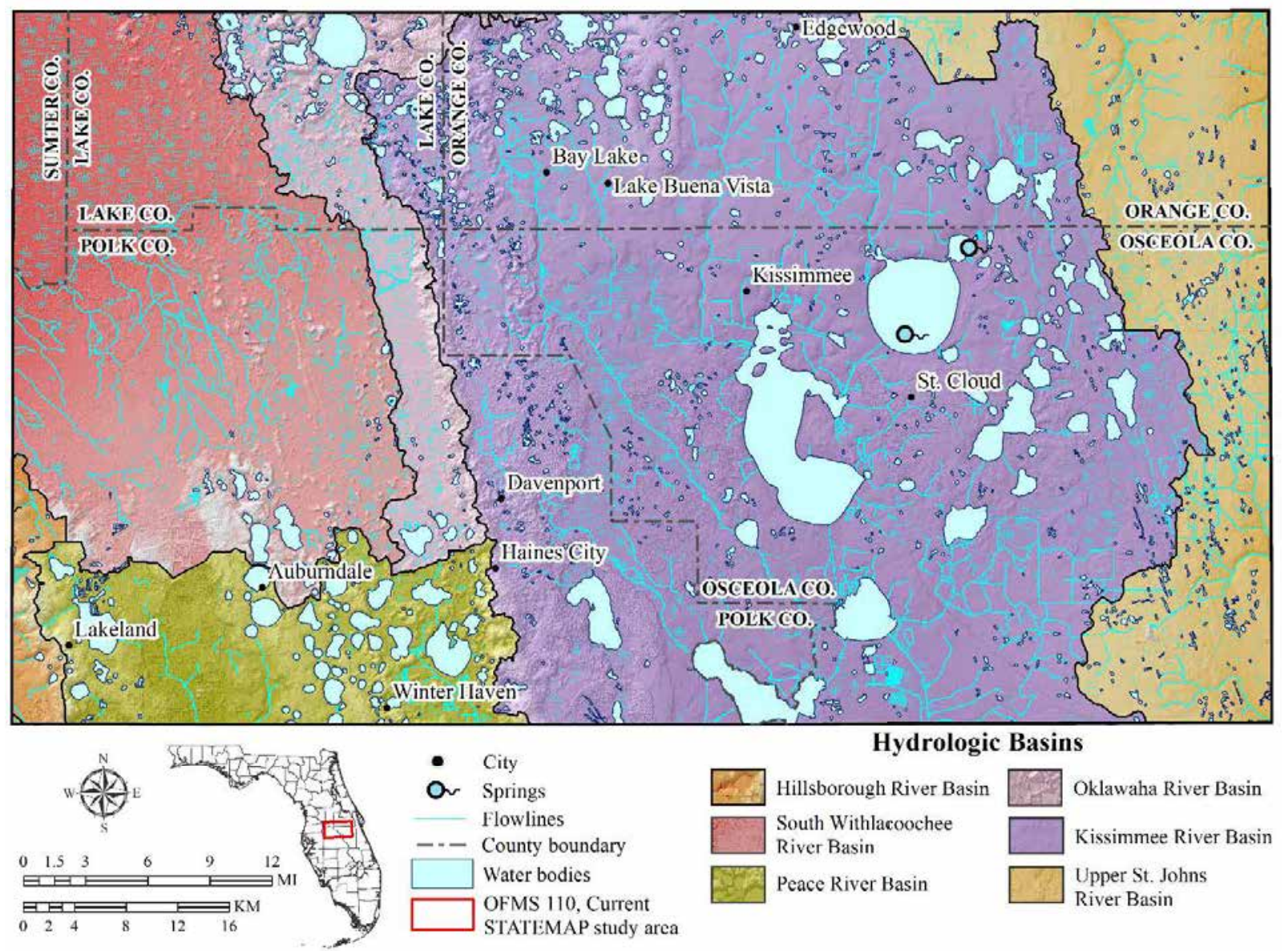

Figure 4. Location of river basins, springs, and other water bodies. 
Karst processes have significantly modified the topography of the region and continue to actively shape it today. Karst topography is characterized by solutional features, subterranean drainage, and caves (Poucher and Copeland, 2006). Infiltration of slightly acidic rain and surface water through preferential pathways, such as joints, fractures, and bedding planes, combined with groundwater fluctuations, cause dissolution of the carbonate rocks (Waltham et al., 2005).

The variability of the karst observed within the study area is closely related to the thickness of overburden and the presence/absence of Cypresshead Formation and Hawthorn Group clays within the sediments mantling the region's carbonate rocks. Those clays are often the sediments which shield carbonate sediments from further dissolution or create a bridge over any cavities which have formed within the sediments and underlying carbonates.

The study area can be divided into two main karst regions: the Ocala Karst District and the Lakes District (see OFMS 110, Plate 3, Figure 3). The Ocala Karst District includes provinces that have comparatively thin overburden sediments relative to the Lakes District. The many provinces within the Lakes District typically have thicker deposits of sand, clay, and clayey sediments ranging from undifferentiated Quaternary deposits to Miocene Hawthorn Group sediments. The Lakes District has many karst lakes, some among the largest in Florida, and the potential for more clayey sediments results in more frequent occurrence of cover-collapse sinkholes. The northern edge of the Hardee Upland in the Peace River District is also impacted by karst and cover-collapse sinkholes, but these occur at a transitional geomorphic boundary and sinkholes are not common over most of the Hardee Upland.

In the eastern portion of the study area, the Osceola Plain in the Barrier Island District does not have abundant karst. Karst is present toward the north where the sedimentary cover over the Eocene limestone thins. Most of the Osceola Plain karst is restricted to cover settlement and sag features (see OFMS 110, Plate 2).

\section{Structure}

Several structural features have affected the geology of the region (Figure 5). The Peninsular Arch, a structurally high area which affected deposition from the Cretaceous to the early Cenozoic, is the dominant subsurface feature of the Florida peninsula (Applin and Applin, 1944; Applin, 1951; Puri and Vernon, 1964; Williams et al., 1977; Schmidt, 1984; Miller, 1986; Scott, 1997). The axis of the Peninsular Arch, which cuts through the eastern portion of the study area, extends from southeastern Georgia to the vicinity of Lake Okeechobee in southern Florida in a general northwest to southeast trend. The crest of the arch passes beneath Alachua County and is highest in Union and Baker counties northwest of the study area. The arch was a topographic high during most of the Cretaceous Period and has Upper Cretaceous sediments deposited upon it (Applin, 1951). It formed a relatively stable base for Eocene carbonate deposition (Williams et al., 1977). The arch did not affect mid-Tertiary to Holocene sediment deposition (Williams et al., 1977; Scott, 1997).

The Ocala Platform is another prominent feature affecting the near surface units within the map area. Hopkins (1920) originally named this feature the Ocala Uplift. Vernon (1951) described the Ocala Uplift as a gentle flexure developed in Tertiary sediments with a northwest-southeast trending crest. Because there is continuing uncertainty about the origin of this feature, Scott (1988) used the term Ocala Platform, rather than Ocala Uplift, or Ocala Arch, since it does not have a structural connotation.

The current study area is on the southeastern flank of the Ocala Platform, which influenced late Tertiary sediment deposition. Miocene sediments of the Hawthorn Group are thought to have 
been deposited across the platform (Scott, 1981a; Scott, 1988; Scott, 1991). Post-Miocene erosion has removed sediments of the Hawthorn Group from much of the crest of the Ocala Platform, exposing Eocene and Oligocene carbonates (Cooke, 1945; Espenshade and Spencer, 1963; Scott, 1981b). This is evident throughout the northwestern portion of the map area where the Ocala Limestone is mapped (OFMS 110; Plate 1).

In addition to the Peninsular Arch and the Ocala Platform, the Kissimmee Quadrangle contains two previously identified subsurface features (Figure 5), the Kissimmee Faulted Flexure and the Osceola Low, both named by Vernon (1951). His "flexure" is actually a high in the middle Eocene Avon Park Formation where the Ocala Limestone and Hawthorn Group sediments may be partially or completely absent due to erosion (Scott, 1988). This feature, which occurs near the southern extents of the Peninsular Arch (Applin, 1951) and Ocala Platform (Vernon, 1951), is the northwest boundary of a downfaulted triangular block with as much as 300 feet of displacement in Osceola County, named the Osceola Low by Vernon (1951). Miocene and younger sediments in the feature are significantly thicker than in adjacent areas.

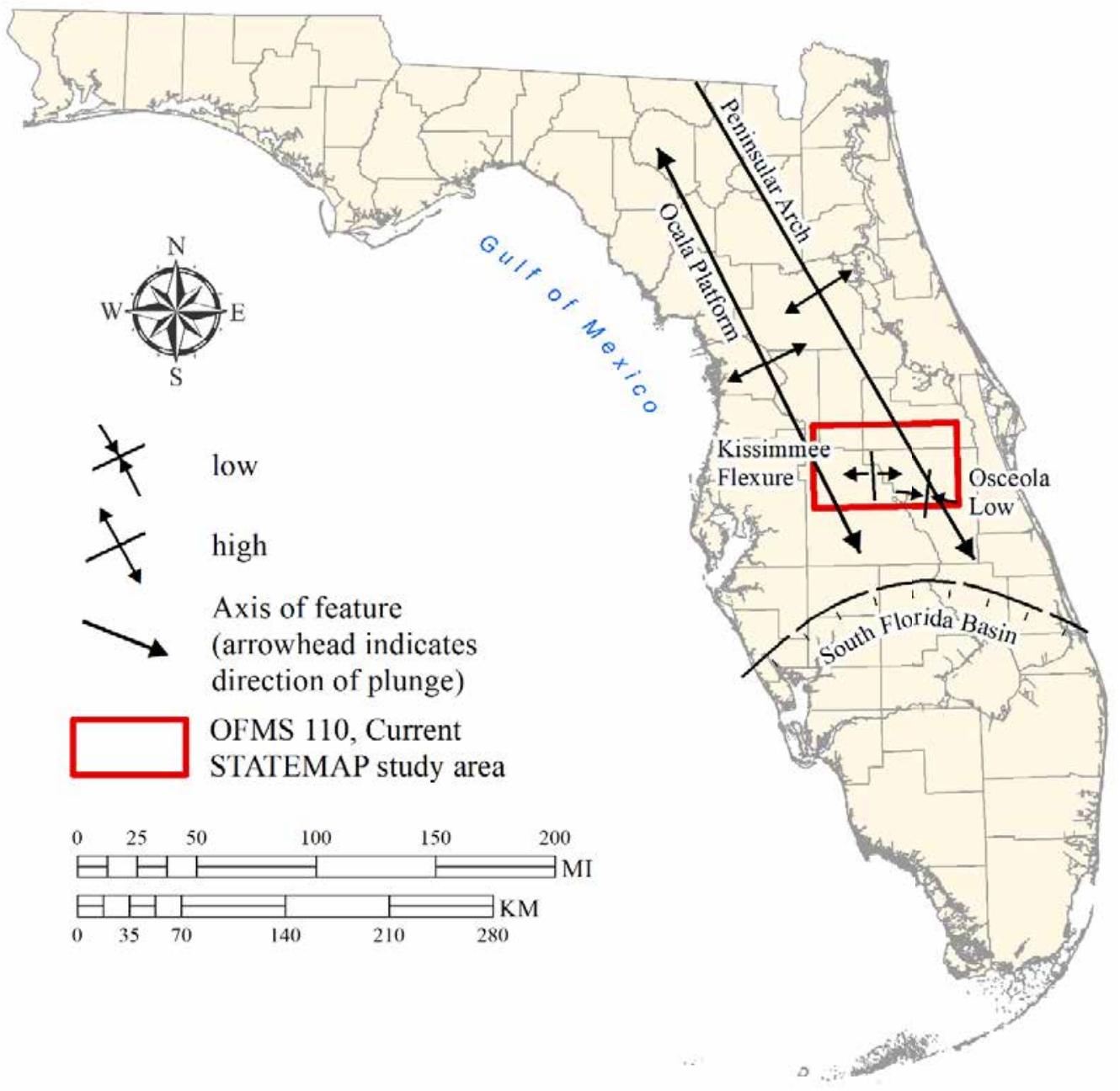

Figure 5. Principal subsurface structures of North Florida (modified from Scott, 1988 and Bryan, et al., 2008). 
While it is apparent, based on borehole data, that there are Eocene limestones close to the surface at the proposed location of the "Kissimmee Faulted Flexure" and thick Miocene and younger deposits infill the "Osceola Low," there is no direct evidence that this is due to large scale fault-bounded structures. Data collected in this study agree with observations previously made by Arthur et al., (2008) and Scott (1988), that there is a stratigraphic high in the Eocene limestone in the region of the Kissimmee Faulted Flexure of Vernon (1951), but that it can be explained better by karst and erosion processes than by invoking structure. The same reasoning holds true for the potential for the Osceola Low to simply be infill on an erosional surface.

The South Florida Basin (Applin and Applin, 1965; Winston, 1971) is a stratigraphic basin which contributed to the southward thickening of Mesozoic and early Cenozoic lithostratigraphic units in the southern Florida peninsula. The reader is referred to Arthur, et al., (2008) and Scott (1988) for a more complete discussion of structural features in the area.

\section{Geomorphology}

The Florida Geological Survey is in the process of producing a new statewide geomorphic map of Florida (Williams et al., in preparation). The new map will synthesize over a century of geomorphic writings and maps about Florida, along with the addition of new data and new interpretations of the geomorphology. The Geomorphology of the Florida Peninsula (White, 1970), in addition to significant work by former FGS colleague, Thomas Scott, are central to the new statewide map. Recent data and technology, including the addition of significant coverage of LiDAR, and new possibilities for digital geomorphological mapping that employ spatiotemporal and geocomputational approaches to data analysis, are allowing the FGS to revise nomenclature and refine boundaries. In the section which follows, all geomorphology unit names and discussions are from Williams et al. (in preparation).

The new map will divide the geomorphology by regional units (districts) and sub-regional to local units (provinces; Figure 6). Districts are defined by regional groupings in which the geomorphology and near-surface geology are combined to form map polygons that are distinct from adjacent districts. Definition of the more localized provinces and their landforms are important for the characterization of the districts.

Given the significance of karst, paleo-shoreline, and marine erosion and deposition in Florida, these processes are important to the identification of both provinces and the regional districts. The study area falls within four geomorphic districts: the Ocala Karst District, the Lakes District, the Peace River District, and the Barrier Island District (OFMS 110; Plate 3, Figure 3). These districts are further subdivided into provinces (OFMS 110; Plate 3, Figure 4). The geomorphic units listed below are discussed in alphabetical, not geographical, order.

\section{Barrier Island District}

The Barrier Island District, characterized by beach ridges, dunes, and relict lagoons, extends into Florida from Georgia southward to the vicinity of Lake Okeechobee (OFMS 110, Plate 3, Figure 3). Beach ridge plains occur in several of the provinces in the district. Of the eight provinces in the district, only the Osceola Plain is present in this study area. Elevations of these beach ridge plains range from sea level in the Atlantic Coastal Complex to about 135 feet (41.1 meters) above mean sea-level (MSL). Drainage in the district is strongly controlled by the relict beach ridges forming distinct trellis drainage. 
Modern coastal processes are dominantly erosional with net littoral and longshore transport from north to south, but there are many depositional coastal features from Pliocene to Recent age in the mapped area. Beach ridge plains represent the preserved depositional features of former shorelines, particularly the shore-parallel dunes. The swales between beach ridges are swampy and contain many lakes, extensive linear swamps and wetlands, and are a nexus for tributary stream development.
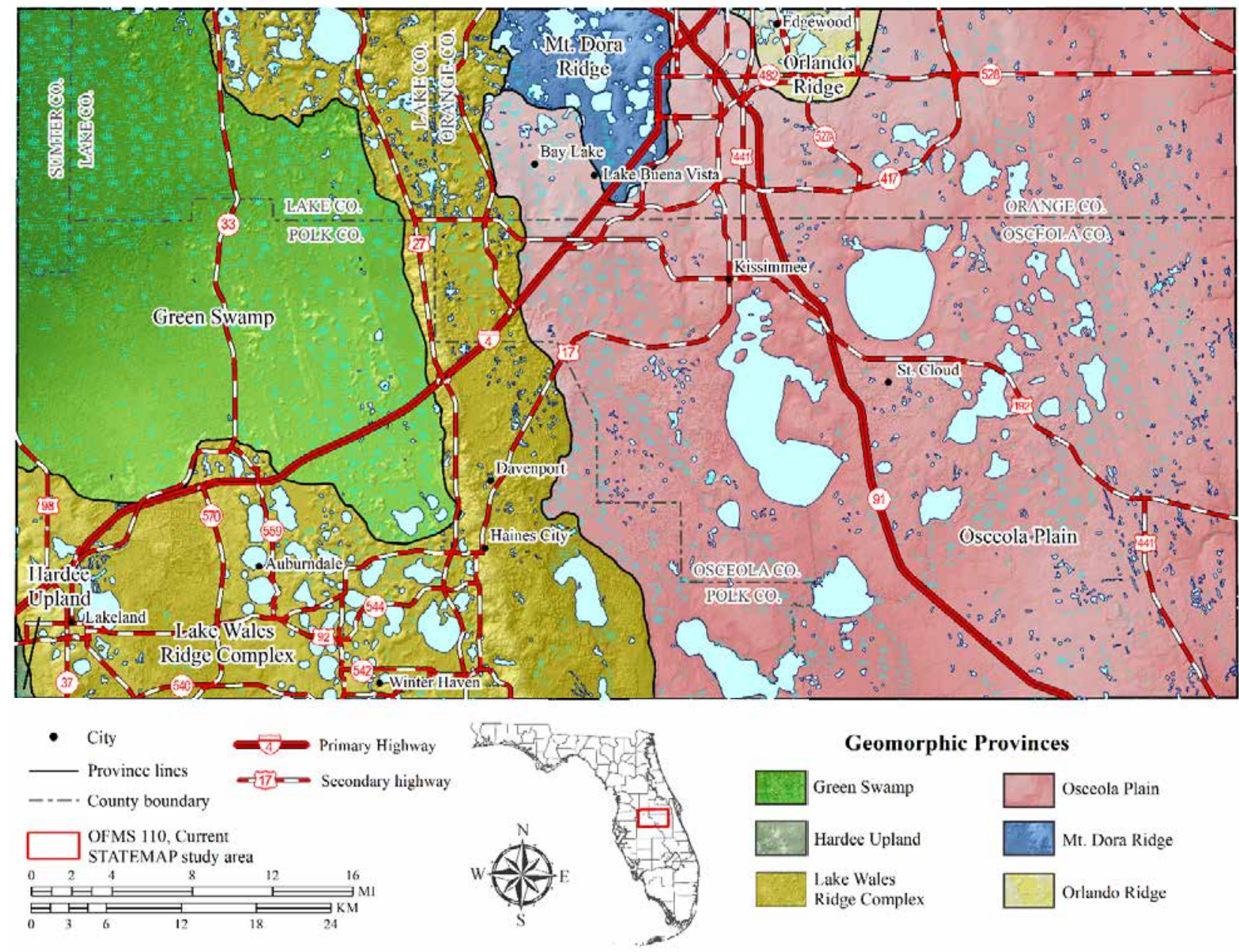

Figure 6. Geomorphic Provinces in the study area (after Williams et al., in preparation).

Relict lagoons are dissected by two major rivers in the Barrier Island District, the St. Johns River and the Kissimmee River. A relict lagoon in the Upper St. Johns River Valley extends uninterrupted from the southern end of the district to southern Volusia County (see OFMS 110, Plate 3, Figure 4). White (1970) recognized a relict lagoon on the western Osceola Plain, now occupied by the Kissimmee River. The entire province is underlain by undifferentiated Tertiary/Quaternary shelly sediments, which supports the lagoon or estuary hypothesis. These rivers also largely follow trellis drainage patterns consistent with coastal depositional landforms.

Cypresshead Formation, undifferentiated Quaternary sediment, or regions geomorphically interpreted as Quaternary beach ridge and dune, dominate the surficial geology over much of the Barrier Island District (see OFMS 110, Plate 1). These lie unconformably on units ranging from the Avon Park Formation to the Hawthorn Group (Scott et al., 2001). The two other most extensive 
surficial geologic units include undifferentiated Tertiary/Quaternary shelly sediments and the Anastasia Formation (east and northeast of the mapped area).

Sinkhole activity is rare in the district. Where observed, it is typically related to dissolution of shell concentrations, particularly mollusks, near the land surface (Upchurch et al., 2015). These are usually expressed as shallow (a few feet, about one meter) cover-settlement features which may form where the undifferentiated Tertiary/Quaternary shelly sediments or Anastasia Formation are present.

\section{Osceola Plain}

The surficial geologic units exposed on the Osceola Plain are undifferentiated Quaternary and Quaternary beach ridge and dune sediments, the latter covering approximately the eastern quarter of the province. Although the Cypresshead Formation occasionally occurs in the subsurface along the western edge of the province, undifferentiated Tertiary/Quaternary shelly sediments are most common beneath the surficial quartz sands. These overlie relatively thin undifferentiated Hawthorn Group sediments to the north and the Peace River and Arcadia formations (Hawthorn Group) as the unit thickens to the south. The Ocala Limestone and Hawthorn Group are missing under part of the northwestern Osceola Plain. Both the Ocala Limestone and Avon Park Formation become more deeply buried from north to south in the province (see OFMS 110, Plate 2). These formations appear to have the most impact on karst landforms in the north near many of the largest lakes in the province.

The province has the topographic form of a terrace, but it is unlikely related to one single stand of sea level (White, 1970). Most of the terrain is relatively flat, with about $80 \%$ of elevations falling between 50 and 75 feet (15.2 and 22.9 meters) above MSL. Elevation and local relief increase to the north where the Econlockhatchee River and other tributaries of the St. Johns River are more developed and incised than other drainages in the province. Elevations range from five feet (1.5 meters) to 120 feet (36.6 meters) above MSL. Highest elevations are rarely above 100 feet (30.5 meters) and occur in the northwest. Elevations of the province within the mapped area range from 30 feet (9.1 meters) to 120 feet (36.6 meters) above MSL.

The Kissimmee River drains much of the western portion of the Osceola Plain southward to Lake Okeechobee and the Everglades. The eastern portion is a beach ridge plain with subtle ridges and swampy swales with trellis drainage, particularly in the Econlockhatchee River basin. Many of the streams flowing east to the St. Johns River run perpendicular to the ridges, but some segments and tributaries show trellis drainage.

Karst features are not common. Shallow sag ponds occur. They are cover-settlement features and likely exist due to dissolution of shallowly buried concentrations of shell material, primarily mollusks, within the Tertiary/Quaternary shelly unit which underlies the majority of the Osceola Plain. In the eastern part of the province, many of these features become elongated parallel to the beach ridge strand plain. Their genesis may be related to the origin of wetlands and swamps in swales, in addition to the dissolution of shell material of the undifferentiated Tertiary/Quaternary shelly sediments.

\section{Lakes District}

The Lakes District occupies most of the Central Highlands of Cooke (1939) in peninsular Florida. The district lies east of the Ocala Karst and Peace River districts, west of the Barrier Island District, and south of the Okefenokee Basin District (OFMS 110, Plate 3, Figure 3). A thick 
sequence of up to 200 feet (61 meters) of siliciclastic and carbonate sediments of the Hawthorn Group, siliciclastic sediments of the Cypresshead Formation and undifferentiated Tertiary/Quaternary sediments overlie the Ocala Limestone in the Lakes District, except from central Polk County and southward, where Suwannee Limestone is present, and where the Ocala Limestone and the Hawthorn Group are locally absent (Arthur et al., 2008).

Dissolution of carbonates and subsequent subsidence or collapse has created the characteristic rolling hills, sinkhole lakes, and dry sinks that dominate the landscape. Portions of the district are internally drained due to the presence of karst features and permeable sand cover. Elevations in the Lakes District vary from less than five feet (1.5 meters) above MSL to nearly 315 feet (96 meters) above MSL. In the study area, the Lakes District includes the Lake Wales Ridge Complex, the Mt. Dora Ridge, and the Orlando Ridge (OFMS 110, Plate 3, Figure 4). The higher elevation regions were once part of an extensive Cypresshead Formation upland that subsequently eroded, leaving remnant highs. The boundaries of the district generally follow the outcrop belt of the Cypresshead Formation in Florida. Topographic relief between the sandy ridges and the karst lakes and depressions can be over 100 feet (30.5 meters) in the hillier regions.

Sea-level fluctuations have influenced landform development of the Lakes District, evident by its coast parallel orientation, and many of its provinces are relict beach ridges associated with deposition of the Cypresshead Formation. In some areas, the distribution of karst lakes is controlled by the beach ridges, with many of the lakes in the ancient swales or on the flanks or toe of the ridges. Drainage is mostly interior with few surface streams other than those draining to the local karst lakes, or occasionally connecting a chain of lakes. Significant exceptions are the Ocklawaha River (and major tributary, the Palatlakaha River) and the St. Johns River, two of the state's larger rivers. These flow through the district, the Ocklawaha having its headwaters and entire valley within the district. The headwaters of the Peace River are also within the Lakes District.

Distinctive circular to sub-circular lakes are visible in aerial photographs, LiDAR, maps, and satellite imagery, revealing the individual sinkholes and coalescing sinkholes which give the Lakes District its name. Dissolution of the limestone and subsequent subsidence or collapse of the overlying siliciclastic sediments has formed karst lakes of varying size and depth, and some exist as wetlands or dry depressions. Swallets are present in the district, but most are small, and few are documented. Springs are also common in the Lakes District, but they are much more abundant in the northern portion.

\section{Lake Wales Ridge Complex}

The Lake Wales Ridge Complex is a remnant of broader uplands, underlain by the Cypresshead Formation, which have a coastal depositional history with numerous ridges. This province has been eroded and lowered by sea-level fluctuations, fluvial erosion, aeolian redistribution of sediments, and karst processes. Elevations range from 50 feet (15.2 meters) to more than 310 feet (94.5 meters) above MSL. Elevations above 180 feet (54.9 meters) MSL are all within the Lake Wales Ridge, Lakeland Ridge, and Lake Henry Ridge. Within the mapped area, elevations range from 60 feet (18.3 meters) to 250 feet (76.2 meters) above MSL.

The area is well drained via the numerous karst features present. The noted exceptions are the Palatlakaha River and the headwaters of the Peace River. Aeolian dune fields are present in many regions. Sediment in these areas often lacks some of the clay that may be present where the Cypresshead Formation is at or near the surface, and water rapidly infiltrates the ground. 
The most common features of the Lake Wales Ridge Complex are numerous karst lakes. The location of the lakes in the province appear to be strongly related to swale locations. Concentrated linearly, largely following the north-northwest to south-southeast trend of the beach ridges, these swales create a trellis drainage pattern of streams and wetlands. Springs are not common except in the northern part of the province. The upper Peace River valley contains several swallets, some in-channel, and others only capturing water during high flow conditions. Mapped and documented swallet features are not common in the remainder of the Lake Wales Ridge Complex.

\section{Mt. Dora Ridge}

The Cypresshead Formation dominates the surficial geology on the Mt. Dora Ridge. The northern part of the province includes several aeolian dune fields mantling the Cypresshead Formation, which is underlain by carbonates of the Hawthorn Group and Ocala Limestone (Scott et al., 2001). Mt. Dora Ridge is a rolling karstic landscape with numerous lakes, more distinct in the south. Elevations within the province range from five feet (1.5 meters) above MSL adjacent to the Lake Plain and the St. Johns River Offset (OFMS 110, Plate 3, Figure 4) to over 190 feet (57.9 meters) above MSL. Relief often exceeds 100 feet (30.5 meters). Elevations within the mapped area range from 90 feet (27.4 meters) to 175 feet (53.3 meters) above MSL.

The sediments of the Cypresshead Formation that form the Mt. Dora Ridge were deposited in a nearshore marine environment. The strong linear component to the karst lakes of the western lobe and southern region display the coastal ridges common to the province. The predominantly interior drainage, and later reworking of surficial sediments in the aeolian dunes of northern Mt. Dora Ridge, has precluded development of trellis drainage. Interior drainage is to the numerous karst lakes, but localized surface flow exists, typically via springs and spring runs, many of which drain east to the St. Johns River.

Karst processes acting through a thick sequence of siliciclastic sediments formed the landscape of karst lakes that are most evident in southern and western Mt. Dora Ridge where there are fewer aeolian dune fields. Several karst lowlands are adjacent to springs on the border and a few in the interior of the province. These lowlands appear to be valleys formed in part by karst processes, having forms more like coalescing sinkholes than fluvially incised valleys.

\section{Orlando Ridge}

The Orlando Ridge is surficially comprised of undifferentiated Quaternary sediments, underlain by the Cypresshead Formation in the northern part of the province. Carbonates in the undifferentiated Tertiary/Quaternary shelly sediments, Hawthorn Group, and Ocala Limestone influence karst landform development via limestone and shell dissolution. Most of the province has ridge-and-swale topography, but this diminishes toward the southwest. The strong northwest to southeast trend of the ridges and swales run subparallel to the modern Atlantic Ocean coastline, revealing that deposition of this landscape was by longshore and littoral processes. Elevations within the province vary from 20 feet (6.1 meters) to 125 feet (38.1 meters) above MSL in the province and from 80 feet (24.4 meters) to 115 feet (35.1 meters) above MSL within the mapped area.

Some internal drainage exists on the Orlando Ridge, mostly via overland drainages that have developed in swales and incipient valleys of karst origin, sometimes both conditions operating together. The karst and swales together are most evident in the northern part of the 
province. Some of the overland drainage includes chains of lakes, but many have been connected by anthropogenic activity in the $20^{\text {th }}$ century. Karst lakes are prominent on the Orlando Ridge. The northern lakes are distinctly aligned with the regional subparallel ridge and swale topography, but karst lakes are common throughout the province. Springs are uncommon, but exist at the northwestern edge of the province.

\section{Ocala Karst District}

The Ocala Karst District encompasses a broad area from central Wakulla County in the panhandle of Florida, south to Hillsborough and Pinellas counties in the west-central peninsula, and inland to nearly the center of the peninsula. The district lies east of the Apalachicola Delta District, south of the Tifton Upland and Okefenokee Basin districts, west of the Lakes District and north of the Peace River District (OFMS 110, Plate 3, Figure 3). The district, which developed in part on the crest of the Ocala Platform, is underlain by carbonates ranging in age from the middle Eocene Avon Park Formation to the Oligocene/Miocene Tampa Member of the Arcadia Formation and the Miocene St. Marks Formation. In the study area, the district is primarily underlain by the upper Eocene Ocala Limestone.

Elevations within the district range from sea level along the Gulf of Mexico to over 300 feet (91.4 meters) above mean sea level (MSL) on the Brooksville Ridge. Green Swamp is the only Ocala Karst District province within the mapped area (OFMS 110, Plate 3, Figure 4). Provinces are delineated based upon several factors including elevation, abundance, type of karst features, drainage, geology, and topographic relief.

The topography over much of the district is gently rolling with only minor relief. However, the relief may exceed 200 feet (61 meters) on the Brooksville Ridge. Dissolution of carbonates has created distinct landforms that characterize the Ocala Karst District, including caves, caverns, springs, sinkholes, siphons, swallets, and resurgences. The southern terminus of the district occurs where siliciclastic sediments of the Hawthorn Group impede the development of karst features and streams and rivers become more common. The entire district has siliciclastic cover of varying thickness ranging from a few feet (1 meter), to as much as 200 feet (61 meters) overlying carbonate rocks.

Dissolution of carbonate sediments forms voids into which the overlying sediments settle, ravel, or collapse. The Ocala Karst District is dominated by solution sinkholes, and shallow, broad, bowl-shaped depressions. These occur in areas where there is a thin, permeable, siliciclastic cover allowing groundwater to slowly dissolve the limestone surface. Areas of the Ocala Karst District with a thicker cover of permeable siliciclastic sediments are characterized by cover-subsidence sinks. These areas have few shallow sinks formed by the downward movement of the siliciclastic cover to fill voids created by the dissolution of carbonate sediments. Cover-subsidence sinkholes develop slowly in response to the dissolution. Cover-collapse sinkholes, which form abruptly, occur in areas where the siliciclastic sediments overlying the limestone are thicker and more cohesive and collapse into voids formed in the carbonate sediments. As siliciclastic sediment thickness increases to the north, south, and east in the district, the type of sinkholes and their abundance changes, grading from solution sinks to cover-collapse sinks. The maturity of the karst varies across the district. In general, the karst is more mature and has less relief due to more extensive carbonate dissolution and erosion of the overlying siliciclastics toward the Gulf coast. Planation by transgressing seas also influenced the geomorphology near the Gulf Coast. 


\section{Green Swamp}

The Green Swamp province is underlain primarily by the upper Eocene Ocala Limestone, which crops out in the Withlacoochee River valley along the western edge of the map area (OFMS 110, Plate 1). The lower Oligocene Suwannee Limestone is present in the southwestern corner of the province. Oligocene/Miocene Hawthorn Group sediments are scattered throughout the province overlying these carbonates. Tertiary/Quaternary Cypresshead Formation and reworked Cypresshead sediments overlie the Hawthorn Group in much of the Green Swamp in the mapped area. Remnant linear ridges of reworked Cypresshead Formation in the eastern part of the province were once part of the Lake Wales Ridge Complex, but are now reduced in elevation through karstification of underlying limestones. Elevations in the province generally increase from west to east and southeast and range from 40 feet (12.2 meters) above MSL to more than 180 feet (54.9 meters) above MSL. Within the mapped area, elevations in the province range from 90 feet (27.4 meters) to more than 180 feet (54.9 meters) above MSL.

The Green Swamp is very poorly drained, and swampy conditions prevail due to the high potentiometric surface of the Floridan aquifer system. Swancar and Hutchinson (1995) suggest that this is largely a result of rejected recharge due to the underlying Ocala Limestone in the province having reduced hydraulic conductivity relative to adjacent regions and compared to the Suwannee Limestone. Headwaters for both the Withlacoochee and Hillsborough rivers are in Green Swamp. Headwaters of the Ocklawaha and Peace rivers occur near the northeastern and southern boundary of Green Swamp, respectively. Karst features are limited due to low hydraulic conductivity and subsurface flow through the underlying limestones. The province contains many shallow, closed topographic depressions formed by solution sinkholes and depositional processes in the thin cover of undifferentiated sediments.

\section{Peace River District}

The Peace River District covers much of west-central peninsular Florida, extending from Hillsborough and Pinellas counties, southward to the Caloosahatchee Valley in Lee and Glades counties. The district lies south of the Ocala Karst District, west of the Lakes District, and northwest of the Everglades District (OFMS 110, Plate 3, Figure 3). Only the Hardee Upland province of the Peace River District is within the mapped area.

Elevations in the district range from sea level to more than 190 feet (57.9 meters) above MSL in the hills among the headwaters of the Alafia River. Within the mapped area, elevations range from 120 feet (36.6 meters) to 155 feet (47.2 meters) above MSL.

Low permeability siliciclastic sediments of the Hawthorn Group underlie the Peace River District allowing the development of numerous rivers and streams, including the Alafia, Little Manatee, Manatee, Myakka, Peace, and their tributaries (Scott et al., 2001). Drainage in the district is predominantly dendritic.

The Peace River District has limited karst development due to the thick cover of Hawthorn Group sediments over most of the region. Karst is limited to sag ponds and swampy areas that develop above shell beds, typically within the undifferentiated Tertiary/Quaternary shelly sediments. Springs occur, but almost all are located near the coastline. Karst features become more common in the north where the Tampa Member of the Arcadia Formation and the Suwannee Limestone approach land surface as the Hawthorn Group clayey sediments thin. Cover-collapse sinkholes occur in the northern part of the district. 
The Ocala Karst District merges with the Peace River District where the Hawthorn Group sediments impede the development of karst features. The transition from the Peace River District to the Lakes District occurs where the low permeability sediments of the Hawthorn Group either become more permeable due to facies changes, or where Hawthorn Group sediments are eroded and no longer retard the development of karst features. The separation of the Peace River District from the Everglades District is defined where the surface-water flow pattern becomes westerly in the Caloosahatchee Valley. The landscape of the Peace River District is relatively flat, with limited relief outside of areas incised by local rivers and hills in the eastern part of the district in the Hardee Upland.

\section{Hardee Upland}

Sand and clayey sand of weathered Hawthorn Group and undifferentiated Quaternary siliciclastic sediments overlie the Hawthorn Group throughout the Hardee Upland (Scott et al., 2001). Hawthorn Group sediments, usually the Peace River Formation, consisting of phosphatic sand, clay, and carbonate, overlie the Suwannee Limestone (Arthur et al., 2008). Carbonates of the Tampa Member of the Arcadia Formation and Suwannee Limestone come near the surface, and karst becomes more prevalent in the northern part of the province. Much of the northern Hardee Upland has been terraformed due to phosphate mining throughout the $20^{\text {th }}$ and into the $21^{\text {st }}$ century.

The Hardee Upland is a broad, south-southeasterly sloped plain. Elevations vary from about 10 feet (3 meters) in the incised river valleys, toward the Gulf of Mexico and Tampa Bay, to over 190 feet (57.9 meters) above MSL. Only a small portion of the province is present in the extreme southwest corner of the mapped area (OFMS 110, Plate 3, Figure 1) where elevations range from 120 feet (36.6 meters) to 155 feet (47.2 meters) above MSL.

The Hardee Upland includes the headwaters and most of the tributaries of the Alafia, Little Manatee, Manatee, and Myakka rivers. Although there are isolated wetland features, most of the region is drained by overland flow, though river corridors can be swampy. Most of the drainage is dendritic, primarily developed on the siliciclastic sediments of the Peace River Formation. The remnant trellis drainage in the upper Peace River may have been inherited from the ridges and swales of the western Lake Wales Ridge Complex to the north, but the ridges and swales are no longer evident in the northeastern Hardee Upland.

Due to the thick cover of Hawthorn Group sediments over much of the province, very few karst features are present on the Hardee Upland. Springs are present mostly in the northwestern province in the Alafia River valley and near the coastline. In the north, the overlying clayey sediments of the Hawthorn Group thin, and limestones of the Tampa Member of the Arcadia Formation and the Suwannee Limestone are near the surface. Cover collapse sinkholes occur in this portion of the Hardee Upland.

\section{HYDROGEOLOGY}

Hydrostratigraphic units within the map area, in ascending order, consist of the Floridan aquifer system (FAS), the intermediate aquifer system/intermediate confining unit (IAS/ICU), and the surficial aquifer system (SAS; Southeastern Geological Society Ad Hoc Committee on Florida Hydrostratigraphic Unit Definition, 1986). The FAS, the primary source for springs and drinking water in the region, is generally comprised of carbonate units of the Avon Park Formation, the Ocala Limestone, the Suwannee Limestone, and the Tampa Member of the Arcadia Formation. The sands, silts, clays and carbonates of the Hawthorn Group (excluding the Tampa Member of 
the Arcadia Formation) comprise the IAS/ICU. The SAS is comprised of the Tertiary/Quaternary Cypresshead Formation, reworked Tertiary/Quaternary Cypresshead Formation, undifferentiated Pliocene/Pleistocene shelly sediments, Tertiary/Quaternary dune sediments, undifferentiated Quaternary sediments, and beach ridge and dune sediments.

Where clayey siliciclastic sediments of the Hawthorn Group and younger units are thick and continuous, they provide confinement for the FAS, but where they are thin, missing or lack significant clay component, karst features often occur, resulting in semi-confined to unconfined conditions.

\section{LITHOSTRATIGRAPHIC UNITS}

\section{Tertiary System}

\section{Eocene Series}

\section{Avon Park Formation}

The middle Eocene Avon Park Formation (Tap), first described by Applin and Applin (1944), is entirely a subsurface unit within the USGS Kissimmee 30 x 60 minute quadrangle. It was encountered in many of the wells utilized for this study and efforts were made to include it in the geologic cross-sections where suitable well coverage existed (see OFMS 110, Plate 2).

Lithology of the Avon Park Formation varies between limestone and dolostone. The limestones consist of cream to light brown to tan, very fine- to medium-grained, poorly to wellindurated, poorly to moderately-well sorted, variably fossiliferous packstone and wackestone, with rare mudstone. The limestones are often interbedded with tan to brown, very poorly to wellindurated, very fine to medium crystalline, fossiliferous, moldic and micro-moldic dolostones. Minor clay beds, organic-rich laminations, and peat flecks may occur. Accessory minerals include chert, pyrite, celestine, gypsum, and quartz (some as doubly-terminated euhedral crystals "floating" in vugs).

Fossils present in the unit include molluscs, foraminifera (Spirolina sp., Lituonella floridana, Bolivina spp., Cushmania [Dictyoconus] americana, Cribrobulimina cushmani, and Fabiana cubensis), echinoids (Neolaganum [Peronella] dalli), algae, and carbonized plant remains. Porosity in the Avon Park Formation is generally intergranular in dolostones and intragranular and moldic in the limestone section. Fracture porosity occurs in the more densely recrystallized dolostone and intercrystalline porosity is characteristic of sucrosic textures. Pinpoint vugs and fossil molds are present to a lesser extent.

Distinction between the middle Eocene Avon Park Formation and the unconformably overlying unit, the upper Eocene Ocala Limestone, can at times be difficult in the study area. Dolomitization of the Avon Park Formation and common recrystallization of both the lowermost Ocala Limestone and the top of the Avon Park Formation has significantly altered the original rock lithology and fabric. Fossil indicators are only somewhat helpful because the latest deposits of the Avon Park Formation and the earliest deposits of the Ocala Limestone are very similar, consistent with deposition in a shallow-water limestone bank or plateau, not unlike the present-day Bahama Banks (Bryan, 2004).

The top of the Avon Park Formation ranges from approximately 320 feet (97.5 meters) below MSL in W-17140 (OFMS 110; Plate 2, cross-section C-C') to approximately 25 feet (7.6 meters) above MSL in W-14080 (OFMS 110; Plate 2, cross-section A-A'). Due to graphical space 
constraints, as well as limited coverage of deeper wells, the total thickness of the Avon Park Formation was not investigated in this study. The Avon Park Formation forms part of the FAS (Southeastern Geological Society Ad Hoc Committee on Florida Hydrostratigraphic Unit Definition, 1986).

\section{Ocala Limestone}

The upper Eocene Ocala Limestone (To), first described by Dall and Harris (1892), is a biogenic marine limestone comprised largely of foraminifera, molluscs, echinoids and bryozoans. The Ocala Limestone sits unconformably on the Avon Park Formation throughout most of the study area. It is thin to absent in an area east of the Lakes District, likely due to erosion and karstification (Scott, 1988; Arthur et al., 2008; see OFMS 110, Plate 2, cross-sections A-A', B-B', F-F', and G-G').

Based on lithologic differences, the Ocala Limestone can be informally subdivided into an upper and lower unit (Scott, 1991). This subdivision, while often apparent in cores and quarries, is often not readily apparent in cuttings. As a consequence of this, the geologic cross-sections do not break out the upper and lower Ocala Limestone. The upper unit is typically a white to cream, fine- to coarse-grained, poorly to well-indurated, poorly to well-sorted, very fossiliferous limestone (predominantly packstone, and grainstone). Fossils commonly include foraminifera (Lepidocyclina ocalana, Nummulites [Camerina] vanderstoki, Nummulites [Operculinoides] ocalana and abundant miliolids), bryozoans, molluscs, and a rich diversity of echinoids. The lower unit is typically a white to cream, fine- to medium-grained, poorly to moderately indurated, moderately to well-sorted limestone (grainstone to packstone). Fossils include foraminifera (Amphistegina pinarensis cosdeni, and abundant miliolids), bryozoans, algae, molluscs, echinoids, and crustaceans.

The Ocala Limestone occurs throughout most of the study area and is at or near the surface along the northwestern portion of the map area (OFMS 110, Plates 1 and 2). The top of the Ocala Limestone ranges from approximately 275 feet (83.8 meters) below MSL in W-11954 (OFMS 110; Plate 2, cross-section G-G') to 75 feet (22.9 meters) above MSL in W-15600 (OFMS 110; Plate 2, cross-section B-B'). Approximately 65 percent of the wells utilized for geologic crosssections penetrate the entire thickness of the Ocala Limestone. In these wells, the thickness of the Ocala Limestone ranges from 155 feet (47.2 meters) in W-872 (OFMS 110; Plate 2, cross-section D-D') to five feet (1.5 meters) in W-10799. The Ocala Limestone is thickest in the southwestern portion of the study area. The Ocala Limestone forms part of the FAS (Southeastern Geological Society Ad Hoc Committee on Florida Hydrostratigraphic Unit Definition, 1986).

\section{Oligocene Series}

\section{Suwannee Limestone}

The lower Oligocene Suwannee Limestone (Ts), named by Cooke and Mansfield (1936), consists of limestone (grainstone and packstone) in the study area. The unit is typically gray, tan, light brown to moderate brown, poorly to well-sorted, moderately to very well-indurated, finely to coarsely crystalline, with limited occurrences of fossiliferous beds. Porosity types include intergranular and moldic. Sedimentary structures include bioturbation and cross-bedding (Budd, 2002). Fossils present in the unit include mollusks, corals, echinoids (including the index fossil 


\section{FLORIDA GEOLOGICAL SURVEY}

Rhyncholampas gouldii), as well as abundant miliolids, and other benthic foraminifera such as Discorinopsis gunteri, Fallotella [Dictyoconus] cookei and Fallotella [Coskinolina] floridana.

The Suwannee Limestone is entirely a subsurface unit in the study area and is only present in a small portion of the southwestern corner of the mapped area. It unconformably overlies the Ocala Limestone and is unconformably overlain by the Arcadia Formation (Hawthorn Group; OFMS 110, Plate 2, cross- sections C-C' and D-D'). The top of the Suwannee Limestone ranges from approximately 17 feet (5.2 meters) below MSL in W-872 (OFMS 110, Plate 2, cross-section C-C' and D-D') to approximately 17 feet (5.2 meters) above MSL in W-13055 (OFMS 110, Plate 2, cross-section C-C'). The full range of Suwannee Limestone thicknesses is better resolved when using data outside the cross-section wells due to the limited occurrence of the formation in the southwest portion of the study area. The thickness of the Suwannee Limestone ranges from approximately 175 feet (53.5 meters) in W-7749 to 15 feet (4.6 meters) in W-18691. The unit thins to the north and east until it is absent due to erosion or non-deposition. Generally, the thickness of the Suwannee Limestone increases to the southwest of the study area.

The Suwannee Limestone, where present, forms part of the FAS (Southeastern Geological Society Ad Hoc Committee on Florida Hydrostratigraphic Unit Definition, 1986).

\section{Oligocene/Pliocene Series}

\section{Hawthorn Group}

Sediments of the upper Oligocene to Pliocene Hawthorn Group are thought to have been deposited over the Ocala Platform throughout the study area, but post-Pliocene erosion and karstification have removed sediments from the crest of the Ocala Platform, exposing Oligocene carbonates in portions of the map area (Cooke, 1945; Espenshade and Spencer, 1963; Scott, 1981b). Hawthorn Group sediments within the study area consist of phosphatic siliciclastics (sands, silts and clay) and carbonates. Fossils in the Hawthorn Group are sparse but may include vertebrate remains, corals, and mollusks. Benthic foraminifera characteristic of the Hawthorn Group include Archaias spp. and Sorites sp.

Within the mapped area, the Hawthorn Group is composed of sediments from the Arcadia Formation (including Tampa Member), Peace River Formation, and undifferentiated Hawthorn Group. The sediments of the Arcadia Formation lie unconformably over the Suwannee Limestone (where the Suwannee Limestone is present in the southwestern corner of mapped area), the Ocala Limestone, or the Avon Park Formation (OFMS 110, Plate 2). The various formations of the Hawthorn Group are, at times, unconformably overlain by undifferentiated Tertiary/Quaternary shelly sediments and/or undifferentiated Quaternary sediments.

In the mapped area, Hawthorn Group sediments are generally missing in the northwestern portion of the quadrangle (OFMS 110, Plate 2, cross-sections A-A' and D-D'). Where present, the undifferentiated Hawthorn Group unconformably overlies the Ocala Limestone (OFMS 110, Plate 2, cross-sections A-A' and D-D'), except for where the Ocala Limestone is missing (OFMS 110, Plate 2, cross-sections A-A', B-B', F-F', and G-G'). In those cases, the Hawthorn Group unconformably overlies the Avon Park Formation. It is unconformably overlain by the Pliocene/Pleistocene Cypresshead Formation, reworked Cypresshead Formation, undifferentiated Pliocene/Pleistocene shelly sediments, and undifferentiated Quaternary sediments (OFMS 110, Plate 2).

Due to the karstic nature of the Lakes District and Osceola Plain, elevations of the Hawthorn Group are highly variable (OFMS 110, Plates 2 and 3). Within the study area, the top 
of the unit may be at a depth of more than 160 feet (48.8 meters) below MSL (OFMS 110; Plate 2, cross-sections B-B' and G-G', W-13676) or exceed 129 feet (39.3 meters) above MSL (OFMS 110; Plate 2, cross-sections C-C' and D-D', W-872). Thickness of the undifferentiated Hawthorn Group varies between 90 feet to zero feet (27.4 to 0 meters). Undifferentiated Hawthorn Group sediments are often clayey sands and only rarely consist of relatively pure clays. The Hawthorn Group generally has low permeability and forms part of the IAS/ICU (Southeastern Geological Society Ad Hoc Committee on Florida Hydrostratigraphic Unit Definition, 1986).

\section{Arcadia Formation}

The upper Oligocene to middle Miocene (Brewster-Wingard et al., 1997) Arcadia Formation (Tha) is a yellowish gray to white, variably sandy (quartz and phosphorite) carbonate, intercalated with beds of siliciclastic-dominant sediments. Although limestone is present, dolostones are most common, ranging in grain size from microcrystalline to medium, with the coarser material being sucrosic. Minor clay and chert beds (some composed of silicified clay) also occur (Upchurch et al., 1982; Scott, 1988). Porosity types include intergranular and moldic. In places within the mapped area, the Arcadia Formation can be further subdivided into the Tampa and Nocatee members, but they only occur in a limited portion of the southwestern corner of the mapped area. The Tampa Member was not encountered in any wells used for cross-sections but was present in several wells in the mapped area so it is included in this report. The Nocatee Member was only ecountered in one well within the extreme souwhwest corner of the mapped area so it is not described herein. For a detailed discussion of the extents and lithology of the Nocatee Member, see Arthur et al. (2008).

The top of the Arcadia Formation ranges from approximately 210 feet (64.0 meters) below MSL (OFMS 110; Plate 2, cross-section B-B', W-13676) to 89 feet (27.1 meters) above MSL (OFMS 110; Plate 2, cross-section C-C', W-872). The unit, thickest in the southwest portion of the study area, ranges from approximately 110 feet (33.5 meters) thick (OFMS 110; Plate 2, crosssection C-C', W-872) to approximately 15 feet thick (4.6 meters; OFMS 110; Plate 2, cross-section C-C', W-15673). See section on undifferentiated Hawthorn Group below for more discussion. The Arcadia Formation forms part of the Intermediate Aquifer System/Confining Unit (IAS/ICU; Southeastern Geological Society Ad Hoc Committee on Florida Hydrostratigraphic Unit Definition, 1986; Arthur et al., 2008).

\section{Tampa Member}

The upper Oligocene to lower Miocene (Brewster-Wingard et al., 1997) Tampa Member of the Arcadia Formation (That) is only present in the southwestern portion of the mapped area, although none of the cross-section wells encountered the unit. The Tampa Member is primarily a limestone that varies from white to yellowish gray in color and ranges from a wackestone to packstone with varying amounts of quartz sand, silt, and clay (Scott, 1988). Phosphate is often absent in the Tampa Member, making this one of the characteristics that aid in distinguishing it from undifferentiated Arcadia Formation sediments. Phosphate can be present, though in amounts less than three percent. Dolomite, silt, and clay are occasionally present though rare. Dolomite is mostly observed near contacts with overlying and/or underlying units such as the undifferentiated Arcadia Formation or dolomitized sections of the Suwannee Limestone. Occasional thin clay beds were observed in core, and less notably in cuttings. These clays are generally light olive to green and can be calcareous and dolomitic. Quartz sand content in the carbonate sections varies from 


\section{FLORIDA GEOLOGICAL SURVEY}

two percent to thirty percent. Sand beds can be found intermittently within the unit. Chert, silicified limestone, and silicified corals are common in the Tampa Member. Fossil molds of foraminifera, mollusks, and gastropods are all common within the Tampa Member. Porosity of the unit is intergranular and moldic.

In the study area, the top of the Tampa Member ranges from approximately 20 feet $(6.1$ meters) above MSL to approximately 65 feet (19.8 meters) above MSL. The maximum observed thickness of the Tampa Member is 70 feet (21.3 meters) in W-7749. The Tampa Member is thinnest at 7 feet (2.1 meters) in W-448. The Tampa member of the Arcadia Formation forms part of the FAS (Arthur et al., 2008).

\section{Peace River Formation}

The middle Miocene to lower Pliocene (Scott, 1988; Covington, 1993) Peace River Formation (Thp) is comprised of yellowish gray to olive gray, interbedded sands, clays, and carbonates with the siliciclastic component being dominant (Scott, 1988). Phosphate sand and gravel are most common in the uppermost beds, although they are interspersed throughout the unit. The Peace River Formation contains a diverse fossil assemblage of marine and terrestrial fauna (e.g., shark teeth, ray spines, horse teeth, dugong, and whale ribs), particularly within the Bone Valley Member. Porosity in the formation is generally intergranular.

The Peace River Formation unconformably overlies several different units in the mapped area (OFMS 110, Plate 2). The Peace River Formation sits unconformably on the Arcadia Formation in the eastern and southern parts of the mapped area (OFMS 110, Plate 2). In the northern and western parts of the mapped area, near the southern extent of the Ocala Platform, the Peace River Formation lies unconformably on the Ocala Limestone or becomes indistinguishable from undifferentiated Hawthorn Group sediments (OFMS 110, Plate 2). In parts of the mapped area the Peace River Formation may lie unconformably on the Arcadia Formation, Ocala Limestone, or Avon Park Formation or may be absent (OFMS 110, Plate2, cross-sections B-B', DD', and F-F'). In areas where the Arcadia Formation is missing, the Peace River Formation sits unconformably on the Ocala Limestone (OFMS 110; Plate 2, cross-sections B-B', D-D', and E-E'). In some areas, the Ocala Limestone is missing and the Peace River sits unconformably on the Avon Park Formation (OFMS 110; Plate 2, cross-sections A-A', and F-F').

The contact between the Peace River Formation and Arcadia Formation can be problematic where both formations become thicker, primarily in the southern and eastern parts of the study area. In these areas, the two units may appear to be conformable, with phosphate-rich siliciclastics grading with depth into more siliciclastic-interbedded carbonates containing generally finergrained and less abundant phosphate (Arthur et al., 2008). In such cases, the lower contact of the Peace River Formation is estimated based on sedimentary structures as well as a best approximation of where the overall lithologic sequence becomes more carbonate dominant (Scott, 1988). In some instances, the presence of a phosphate lag deposit can help distinguish the contact between the Peace River and Arcadia formations.

The top of the Peace River Formation ranges from 160 feet (48.8 meters) below MSL in W-13676 (OFMS 110; Plate 2, cross-section B-B') to 129 feet (39.3 meters) above MSL in W-872 (OFMS 110; Plate 2, cross-section C-C'). Thicknesses range from 110 feet (33.5 meters) in W6476 (OFMS 110; Plate 2, cross-section F-F') to 5 feet (1.5 meters) in W-15673 (OFMS 110; Plate 2, cross-section C-C').

The Peace River Formation is within the upper portion of the IAS/ICU and is a confining

to semi-confining lithostratigraphic unit. The Peace River Formation and undifferentiated 
Hawthorn Group sediments comprise a low-permeability confining to semi-confining facies within the IAS/ICU within the study area. (Southeastern Geological Society Ad Hoc Committee on Florida Hydrostratigraphic Unit Definition, 1986).

\section{Bone Valley Member}

The middle Miocene to lower Pliocene (Webb and Crissinger, 1983) Bone Valley Member of the Peace River Formation (Thpb) is lithologically very similar to the Peace River Formation. The lithology of the Bone Valley Member differs in that it contains higher concentrations of coarse-grained phosphate (more than 30 percent by volume), ranging up to gravel-size nodules. Some pebble sized grains show evidence of reworking, boring structures, and multiple stages of phosphatization. Phosphate coloration ranges from black and brown to cream and white. The nonphosphorite component of the Bone Valley Member is comprised of quartz sand and clay (e.g. palygorskite and sepiolite; Scott, 1988), occasionally with minor amounts of dolomite. Carbonate beds are not present; however, limestone and dolostone cobbles may be present (Tom Scott, personal communication, 2005). According to Scott (1988, p. 87), "the occurrence of phosphate gravels in the Bone Valley Member is the most lithologically important factor in the separation of the member from the remainder of the Peace River Formation.” Scott (1988) also notes that the contact between the Bone Valley Member and the Peace River Formation is gradational, both laterally and vertically. While the Bone Valley Member can often be separated from the remainder of the Peace River Formation in cores and mines, it is rarely possible to differentiate in cuttings.

After looking at dozens of sets of cuttings and cores throughout the study area, the authors determined that the Bone Valley Member, as defined by Scott (1988), could not reliably be mapped at this scale in the study area. This is due to a combination of several factors including the gradational nature of the contacts, lithological similarities between the Bone Valley Member and the Peace River Formation, poor core control, and significant amounts of phosphate mining activities during the last century.

It should be noted that the areas mapped as Bone Valley Member in Arthur et al. (2008) and Scott (1988) were based on a very limited number of wells, and the boundaries of the unit were heavily influenced by the presence of phosphate mines. Mining in the phosphate district is driven by economics and thus they historically mined phosphate-rich zones, not only the Bone Valley Member lithostratigraphic unit as defined by Scott (1988).

The southwestern part of the mapped area has been extensively mined for phosphate (Figure 7) going as far back as 1890 (Sellards, 1915). As a result, much of the area formerly mapped as Bone Valley Member by Scott (1988) and Arthur et al. (2008) has been removed and/or reclaimed, and the surficial sediments no longer truly represent the original lithology. This also proved to be an issue when working with core and cutting samples that have been collected over the span of the past 100 years. These samples often had incomplete location and elevation information, making the determination of the top of the Bone Valley Member problematic at best. Without reliable information on boreholes located in mined areas and specific locations and elevations, the authors were unable to determine if the various samples examined were collected pre- or post-mining in many instances. After much discussion with various staff geologists (including Tom Scott), it was determined that it was best to map the area as Peace River Formation and forego attempts to delineate the Bone Valley Member at this scale. The reader is referred to Scott (1988) and Arthur et al. (2008) for the former extents and additional discussion of the Bone Valley Member. 


\section{Hawthorn Group (Undifferentiated)}

In northwestern portions of the mapped area, similar lithologies of the lower Peace River Formation and upper Arcadia Formation, combined with post-depositional reworking of Hawthorn Group sediments, makes consistently differentiating the Peace River and Arcadia formations difficult in cores and impossible in cuttings, particularly where the Hawthorn Group sediments are thin. Based solely upon lithology, and due to overall siliciclastic content, many of these sediments could be considered Peace River Formation. In these instances, since the sediments could not be reliably broken out as either Peace River or Arcadia formations, they were designated as undifferentiated Hawthorn Group.

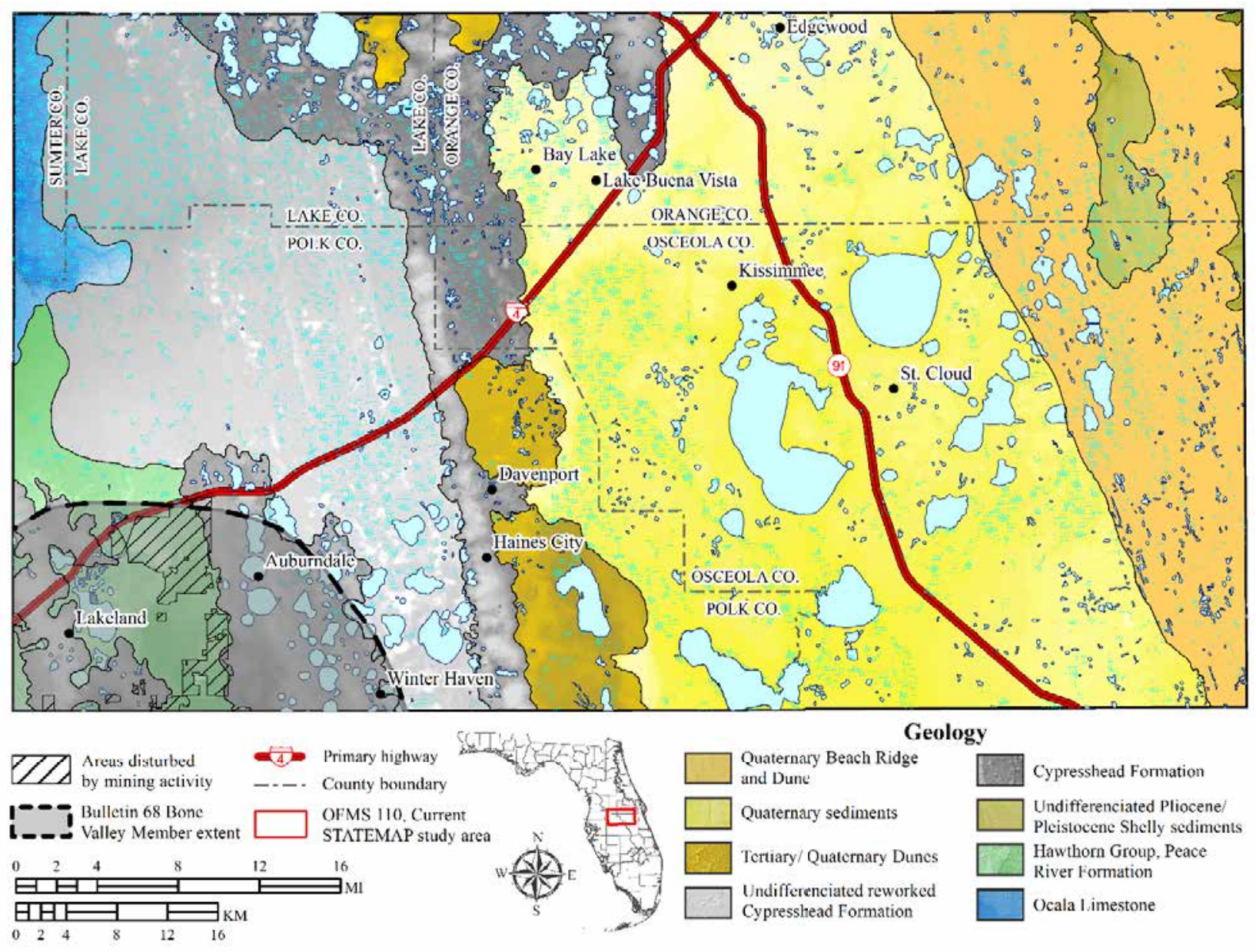

\section{Figure 7. Phosphate mining areas with extents of Bone Valley Member from Arthur et al.} (2008).

These undifferentiated Hawthorn Group sediments lie unconformably above the Eocene Ocala Limestone in the northwestern portion of the mapped area (OFMS 110; Plate 2, cross Section A-A', and E-E'). Undifferentiated Hawthorn Group sediments within the mapped area (see OFMS 110, Plate 2, cross-sections A-A' and E-E') consist of yellowish brown, grayish orange, and greenish to light olive gray, poorly to moderately consolidated, clayey sands to silty clays and occasional relatively pure clays, silt-sized dolomite cemented sands, and variably quartz sandy 
dolostones. The clays are often expansive and can be silicified. Phosphate sand and gravel is a highly variable but consistent component. Phosphate grains present range from off-white in color (highly weathered) to progressively darker browns and blacks (less weathered). The upper portion of the undifferentiated Hawthorn Group is often highly weathered and may contain little to no phosphate due to leaching.

Within the study area, the top of the unit ranges from 25 feet (7.6 meters) above MSL to 50 feet (15.2 meters) above MSL (OFMS 110; Plate 2, cross-sections A-A' and E-E'). The undifferentiated Hawthorn Group ranges from 25 feet thick (7.6 meters; OFMS 110; Plate 2, crosssections A-A' and E-E', W-8393) to 10 feet thick (3.1meters; OFMS 110; Plate 2, cross-section A$\left.A^{\prime}, \mathrm{W}-14247\right)$.

The undifferentiated Hawthorn Group sediments generally have low permeability and form part of the IAS/ICU (Southeastern Geological Society Ad Hoc Committee on Florida Hydrostratigraphic Unit Definition, 1986).

\section{Tertiary/Quaternary Systems}

\section{Pliocene/Pleistocene Series}

\section{Cypresshead Formation}

The Pliocene/Pleistocene Cypresshead Formation (TQc), is a mottled reddish-brown to reddish-orange to white, unconsolidated to poorly consolidated, fine-to very coarse-grained, variably clayey to clean quartz sand. Cross-bedded sands and bimodal sand size distributions are common within this formation. Discoid quartzite pebbles, heavy mineral grains, and mica are often present. Ghosts of nearshore marine mollusks and burrows are rare. The Cypresshead Formation is present throughout much of the study area and forms the core of the various ridges present in the region. The lower portion of the Cypresshead Formation frequently becomes a more weathered, finer-grained, well-sorted sand and silt. In cores, the unit is often characterized by beds of finegrained, well-sorted sand with thin layers of clay dispersed through the sand. Occasional coarse sand beds may occur.

The Cypresshead Formation sits unconformably on the undifferentiated Hawthorn Group or Ocala Limestone in the northern part of the mapped area (OFMS 110; Plate 2, cross-sections A-A' and E-E'). In the southern part of the mapped area, where the Lake Wales Ridge becomes much more narrow, the Cypresshead Formation sits unconformably on the Peace River Formation (OFMS 110; Plate 2, cross-sections C-C' and E-E'). In the southwestern part of the mapped area the Cypresshead Formation sits unconformably on the Peace River Formation (OFMS 110; Plate 2, cross-sections C-C' and D-D').

Elevations of the top of the unit range from 75 feet (22.9 meters) above MSL to over 225 feet (68.6 meters) above MSL in the mapped area. Cypresshead Formation thickness ranges between 200 feet (61 meters) to zero in study area wells.

Permeable sediments of the Cypresshead Formation form part of the surficial aquifer system (SAS; Southestern Geological Society Ad Hoc Committee on Florida Hydrostratigraphic Unit Definition, 1986). 


\section{FLORIDA GEOLOGICAL SURVEY}

\section{Undifferentiated reworked Cypresshead Formation}

Sediments mapped as undifferentiated reworked Cypresshead Formation (TQuc) in the study area are the result of post-depositional reworking of Cypresshead Formation sediments. The reworked Cypresshead Formation sediments can range from white to gray to orange to light brown to grayish brown. They are fine to coarse quartz sands with scattered quartz gravel and varying percentages of clay in the matrix (Scott, 2001). They are generally lower in elevation and have less relief than Cypresshead Formation sediments. They are primarily present along the western flank of the Lake Wales Ridge Complex in the mapped area and along the southeastern flank of the Lake Wales Ridge south of Haines City (OFMS 110, Plate 2, cross section C-C' and Plate 3). Several relict ridges exist parallel to the Lake Wales Ridge Complex extending into the Green Swamp. The authors of this study believe, based on limited field exposures, pits, and borehole data, that these ridges were likely originally deposited as Cypresshead Formation and have been subsequently reworked during sea-level fluctuations and modified by karst processes. While some of the pit exposures and the cores through some of these smaller ridges appeared to be Cypresshead Formation, they were too small to map and a decision was made to include these in the reworked Cypresshead Formation unit.

Elevations of the top of the reworked Cypresshead Formation range from 75 feet (22.9 meters) above MSL to 150 feet (45.7 meters) above MSL in the mapped area. Thickness of these sediments range from 100 feet (30.5 meters) to 7 feet (2.1 meters).

Permeable sediments of the reworked Cypresshead Formation form part of the surficial aquifer system (SAS; Southeastern Geological Society Ad Hoc Committee on Florida Hydrostratigraphic Unit Definition, 1986).

\section{Pliocene/Pleistocene shelly sediments}

A sequence of undifferentiated Pliocene/Pleistocene shelly sediments (TQsu) lies east of the Lake Wales Ridge Complex and occupies the section where the Eocene carbonates and overlying Hawthorn Group are at significantly deeper depths compared to other areas within the mapped area. Huddlestun (1988) named this unit the Nashua Formation. Much of the evidence listed by Huddlestun (1988) was based on biostratigraphic correlation and not lithologic distinction. Sediments located along the Econlockhatchee River were investigated during fieldwork for mapping in the Orlando quadrangle (Green et al,. 2015a; Green et al., 2015b) project were determined to be very young (late Pleistocene-Holocene, Roger Portell, personal communication). Given the age uncertainty of these units, lack of adequate core control and lack of access to the type section, the authors have decided to utilize the convention of the Scott et al. (2001) and map these sediments informally as undifferentiated Pliocene/Pleistocene shelly sediments. These sediments lie unconformably on either the Avon Park Formation, the Ocala Limestone, or the Peace River Formation (OFMS 110; Plate 2, cross-sections A-A', B-B', C-C', F$F^{\prime}$, and G-G'). Huddlestun (1988) indicated that the unit grades laterally into the Cypresshead Formation in the vicinity of the Trail Ridge (north of the mapped area). Evidence from mapping in the Orlando quadrangle (Green et al., 2015a; Green et al., 2015b), however, indicated that the unit is, at least in part, older than the Cypresshead Formation. This may be a result of prograding of Cypresshead Formation sediments over Pliocene/Pleistocene shelly marine sediments during changes in sea level. Some of these fossiliferous sands just north of the study area (in the Daytona Beach quadrangle) are Pliocene (Roger Portell, personal communication). The majority of the 
Pliocene/Pleistocene shelly sediments present in the study area are generally below 50 feet (15.2 meters) MSL.

There are some boreholes where the elevations of the Pliocene/Pleistocene shelly sediments exceeds this in the eastern part of the mapped area where the Econlockhatchee River and other streams drain the Quaternary beach ridge and dune (Qbd) sediments. It is postulated that these instances of higher elevation Pliocene/Pleistocene shelly sediments are indicative of paleoshorelines that have been "stranded" due to sea-level fluctuation and the influence of dynamic topography. Additional studies are needed to determine the exact nature and relationships of these units in the region.

These undifferentiated Pliocene/Pleistocene shelly sands are overlain by reworked Cypresshead Formation and Tertiary/Quaternary dunes on the eastern flank of the Lake Wales Ridge Complex in the south-central portion of the mapped area (OFMS 110, Plate 2, cross-section C-C'). In the eastern two-thirds of the mapped area, the unit is unconformably overlain by undifferentiated Quaternary sediments or Quaternary beach ridge and dune sediments.

Undifferentiated Pliocene/Pleistocene shelly sediments disconformably overlie the Peace River Formation throughout the study area east of the Lake Wales Ridge Complex, except in instances where the Peace River Formation is missing. In those cases, the Pliocene/Pleistocene shelly sediments unconformably overlie either the Ocala Limestone or the Avon Park Formation (OFMS 110, Plate 2, cross-sections B-B', and F-F'). There are problems in mapping these sediments as separate units because their historical definition is based on biostratigraphic, not lithostratigraphic, criteria (Scott and Allmon, 1990; Scott and Wingard 1995). Scott and Campbell (1993) informally applied the name Okeechobee formation to these sediments in an effort to provide a lithostratigraphic framework. McCartan and Moy (1995) mapped several units southwest of this area (Sarasota quadrangle) based upon inferred ages from fossils, stratigraphic position, and isotope age dates. Due to the similar lithologies of these units, difficulties encountered in attempting to differentiate them in drill cuttings, and the fact that the Okeechobee formation was never formalized, they are placed within the undifferentiated Pliocene/Pleistocene shelly sediments on this map.

Undifferentiated Pliocene/Pleistocene shelly sediments typically consist of fine-to-medium quartz sand with variable amounts of calcilutite, silt, marine mollusk shells, and clay. Colors range from light gray to light olive gray. Shells, which may vary from whole to fragments, are normally highly weathered and abraded and may occasionally become the dominant lithology. Other accessory minerals may include calcite, aragonite, mica, heavy minerals, and minor phosphate sand and gravel. A basal phosphate lag is often present. In the study area, Pliocene/Pleistocene shelly sediments are predominantly in the form of unconsolidated sands with varying percentages of shell fragments. Calcite cemented Pliocene/Pleistocene shelly sediments were encountered, albeit less frequently than unconsolidated material.

The top of the undifferentiated Pliocene/Pleistocene shelly sediments ranges from 80 feet (24.4 meters) below MSL east of the Lake Wales Ridge (OFMS 110; Plate 2, cross-section C-C', W-15673) to 60 feet (18.3 meters) above MSL in W-17020 (OFMS 110; Plate 2, cross-section B$\left.B^{\prime}\right)$. The thickness of the undifferentiated Pliocene/Pleistocene shelly sediments in the crosssection wells varies from 210 feet (64 meters) in W-13676 (OFMS 110; Plate 2, cross-sections B$\mathrm{B}^{\prime}$ and G-G' ) to 15 feet (4.6 meters) in W-15673 (OFMS 110; Plate 2, cross-section C-C').

Permeable sediments of the undifferentiated Pliocene/Pleistocene shelly sediments form

part of the SAS (Southeastern Geological Society Ad Hoc Committee on Florida Hydrostratigraphic Unit Definition, 1986). 


\section{FLORIDA GEOLOGICAL SURVEY}

\section{Tertiary/Quaternary dunes}

Tertiary/Quaternary dunes (TQd), while not a formally recognized lithostratigraphic unit, are mapped following the convention of Scott et al. (2001) in order to facilitate a better understanding of Florida's geology. Where LiDAR is available, these dunes are readily differentiated from other units by their distinct topographic expression. These dune sediments are fine-to-medium quartz sand with varying amounts of disseminated organic matter. They are generally found at elevations above 100 feet (30.5 meters) MSL, although there are areas along the flanks of the Lake Wales Ridge where elevations of these dune sands can be lower. Sands forming these dunes are derived from re-working of sediments from the Cypresshead Formation (TQc) and undifferentiated Quaternary sediments $(\mathrm{Qu})$. There are small portions along the eastern flank of the Lake Wales Ridge which have Tertiary/Quaternary dune sediments mapped (OFMS 110, Plate 1). These sediments are considered part of the SAS (Southeastern Geological Society Ad Hoc Committee on Florida Hydrostratigraphic Unit Definition, 1986).

\section{Pleistocene to Holocene Series}

\section{Undifferentiated Quaternary sediments}

Undifferentiated Quaternary sediments $(\mathrm{Qu})$ in the study area predominantly lie unconformably on the Hawthorn Group, undifferentiated Pliocene/Pleistocene shelly sediments, or Cypresshead Formation (OFMS 110, Plate 2, cross-sections). The undifferentiated Quaternary sediments present in the mapped area may be highly variable in thickness.

Generally, these undifferentiated Quaternary sediments consist of white to gray to orange, fine- to coarse-grained, clean to clayey unfossiliferous quartz sands, sandy clays, and clays with variable admixtures of organics. Several boreholes east of the Lake Wales Ridge Complex penetrate sediments with lithologic characteristics of the basal Cypresshead Formation (including coarse sands, some clay, and mica). However, given the effects of sea-level fluctuations east of the Lake Wales Ridge and because they could not be correlated with known Cypresshead Formation occurences, they were mapped as Qu.

The undifferentiated Quaternary sediments form part of the SAS (Southeastern Geological Society Ad Hoc Committee on Florida Hydrostratigraphic Unit Definition, 1986).

\section{Quaternary beach ridge and dune}

Quaternary beach ridge and dune sediments (Qbd) are a subdivision of the undifferentiated Quaternary sediments that are mapped on the basis of having a surficial expression of relict beach ridges and dunes. While not a formally recognized lithostratigraphic unit, it is mapped following the convention of Scott et al. (2001) in order to facilitate a better understanding of Florida's geology. This unit unconformably overlies undifferentiated Pliocene/Pleistocene shelly sediments (TQsu), in the eastern part of the study area (OFMS 110; Plates 1 and 2).

Beach ridge and dune sediments are dominantly siliciclastic sands with occasional shells and are unconsolidated to poorly consolidated. Organics typically occur as disseminated organic matrix, roots and plant debris, carbonized remains, or charcoal. The unit is considered part of the SAS (Southeastern Geological Society Ad Hoc Committee on Florida Hydrostratigraphic Unit Definition, 1986). 


\section{DERIVATIVE PRODUCTS}

Several derivative products will benefit from data generated for this project. During the mapping project, data from over 380 wells with samples were analyzed. Formation picks, made on selected wells with cores and cuttings samples, allow creation of a structure contour map of the top of the FAS, along with the construction of structure contour and isopach maps of the IAS/ICU in the area. They will also allow for structure contour maps and isopach maps of several of the geologic units within the mapped area. Additional derivative products anticipated to come from this mapping effort include aquifer vulnerability assessment maps. Data derived from prior STATEMAP products have often been used to augment other Florida Geological Survey projects around the state (Arthur et al., 2007; Arthur et al., 2017). 


\section{REFERENCES}

Applin, P., 1951, Possible future petroleum provinces of North America - Florida: American Association of Petroleum Geologists Bulletin, v. 35, p. 405-407.

Applin, P.L. and Applin, E.R., 1944, Regional subsurface stratigraphy and structure of Florida and southern Georgia: American Association of Petroleum Geologists Bulletin, v. 28, p. 16731753.

Applin, P.L., and Applin, E.R., 1965, The Comanche Series and associated rocks in central and south Florida: U.S. Geological Survey Professional Paper 447, 84 p.

Arthur, J.D., Fischler, C., Kromhout, C., Clayton, J.M., Kelley, G.M., Lee, R.A., Li, L., O’Sullivan, M., Green, R.C., and Werner, C.L., 2008, Hydrogeologic framework of the Southwest Florida Water Management District: Florida Geological Survey Bulletin 68, 102 p.

Arthur, J.D., Wood, H.A.R., Baker, A.E., Cichon, J.R., and Raines, G.L., 2007, Development and implementation of a Bayesian-based aquifer vulnerability assessment in Florida: Natural Resources Research, v. 16, p. 93-107.

Arthur, J.D., Baker, A.E., Cichon, J.R., Wood., A.R., and Rudin, A., 2017, Florida Aquifer Vulnerability Assessment: Contamination Potential Models of Florida's Principal Qquifer Systems: Florida Geological Survey Bulletin 67, 148 p. 66 fig., 18 tables, 2 appendices, 3 plates.

Brewster-Wingard, G.L., Scott, T.M., Edwards, L.E., Weedman, S.D., and Simmons, K.R., 1997, Reinterpretation of the peninsular Florida Oligocene: an integrated stratigraphic approach: Sedimentary Geology, v. 108, p. 207-228.

Bryan, J.R., 2004, Larger foraminifera: Introduction, biology, ecology, taxonomic and stratigraphic listings and comments on Florida fossil assemblages: Florida Paleontological Society, Florida Fossil Invertebrates, Part 6, 28 p.

Bryan, J.R., Scott, T.M., and Means, G.H., 2008: Roadside Geology of Florida: Mountain Press Publishing Company, Missoula, Montana, 376 p.

Budd, D.A., 2002, The relative roles of compaction and early cementation in the destruction of permeability in carbonate grainstones: A case study from the Paleogene of west-central Florida, USA: Journal of Sedimentary Research, v. 72, p. 116-128.

Campbell, K.M., 1993a, Geologic map of Sumter County, Florida: Florida Geological Survey Open-File Map Series 40, scale 1:126,720.

,1993b, Geologic map of Polk County, Florida: Florida Geological Survey Open-File Map Series 46, scale 1:126,720.

Cooke, C.W., 1939, Scenery of Florida interpreted by a geologist: Florida Geological Survey Bulletin 17, $120 \mathrm{p}$. 
, 1945, Geology of Florida: Florida Geological Survey Bulletin 29, 339 p.

Cooke, C.W., and Mansfield, W.C., 1936, Suwannee limestone of Florida (abstract): Geological Society of America Proceedings 1935, p. 71-72.

Copeland, R., Doran, N.A., White, A.J., and Upchurch, S.B., 2011, Regional and statewide trends in Florida's spring and well groundwater quality (1991-2003): Florida Geological Survey Bulletin 69 (Revised), 393 p.

Covington, J.M., 1993, Neogene nannofossils of Florida, in Zullo, V.A., Harris, W.B., Scott, T.M., and Portell, R.W., eds., The Neogene of Florida and adjacent regions: Florida Geological Survey Special Publication 37, 112 p.

Dall, W.H., and Harris, G.D., 1892, Correlation papers, Neocene: U.S. Geological Survey Bulletin 84, $349 \mathrm{p}$.

Espenshade, G.H., and Spencer, C.W., 1963, Geology of phosphate deposits of northern peninsular Florida: United States Geological Survey Bulletin 1118, 115 p.

Green, R.C., Williams, C.P., Burdette, K.E., Bassett, S.W., Flor, A.D., and Paul, D.T., 2011, Geologic map of the eastern portion of the USGS Inverness 30 × 60 minute quadrangle, central Florida: Florida Geological Survey Open-File Map Series 102, scale 1:100,000, 3 plates.

Green, R.C., Evans, W.L., Williams, C.P., Kromhout, C., and Hannon, L.M., 2012a, Geologic map of the USGS Tarpon Springs 30 x 60 minute quadrangle, central Florida: Florida Geological Survey Open-File Map Series 104, scale 1:100,000, 3 plates.

Green, R.C., Evans, W.L., Williams, C.P., Kromhout, C., and Hannon, L.M., 2012b, Text to accompany geologic map of the USGS Tarpon Springs 30 x 60 minute quadrangle, central Florida: Florida Geological Survey Open-File Report 98, 40 p.

Green, R.C., Williams, C.P., Bambach, P.W., Hannon, L.M., Apolinar, B., Campbell, K.M., and Dyer, S.B., 2015a, Geologic map of the USGS Orlando 30 x 60 minute quadrangle, central Florida: Florida Geological Survey Open-File Map Series 107 104, scale 1:100,000, 3 plates.

Green, R.C., Williams, C.P., Bambach, P.W., Hannon, L.M., Apolinar, B., Campbell, K.M., and Dyer, S.B., 2015b, Text to accompany geologic map of the USGS Orlando 30 x 60 minute quadrangle, central Florida: Florida Geological Survey Open-File Report 104, 37 p.

Green, R.C., Apolinar, B., Williams, C.P., White, K. M., Bassett, S.W., and Nason, L.F., 2017a, Geologic map of the USGS St. Petersburg 30 x 60 minute quadrangle, west-central Florida: Florida Geological Survey Open-File Map Series 109, scale 1:100,000, 3 plates.

Green, R.C., Apolinar, B., Williams, C.P., White, K. M., Bassett, S.W., and Nason, L.F., 2017b, Text to accompany geologic map of the USGS St. Petersburg $30 \times 60$ minute quadrangle, west-central Florida: Florida Geological Survey Open-File Report 106, 41 p. 
Hopkins, O.B., 1920, Drilling for oil in Florida: U.S. Geological Survey Press Bulletin, April, 1920.

Huddlestun, P.F., 1988, A revision of the lithostratigraphic units of the Coastal Plain of Georgia, the Miocene through Holocene: Georgia Geologic Survey Bulletin 104, 262 p.

Jones, G.W., Upchurch, S.B., and Champion, K.M., 1996, Origin of nitrate in groundwater discharging from Rainbow Springs, Marion County, Florida: Southwest Florida Water Management District Report, 155 p.

McCartan, L., and Moy, W., 1995, Geologic map of the Sarasota and Arcadia, Florida, 30 x 60 minute quadrangles: United States Geological Survey Open-File Report 95-261, scale 1:100,000, 5 plates.

Miller, J.A., 1986, Hydrogeologic framework of the Floridan aquifer system in Florida and in parts of Georgia, Alabama, and South Carolina: Regional Aquifer-System Analysis: U.S. Geological Survey Professional Paper 1403-B, 91 p., 33 plates.

Poucher, S. and Copeland, R., 2006, Speleological and karst glossary of Florida and the Caribbean: Gainesville, University Press of Florida, 196 p.

Puri, H.S. and Vernon, R.O., 1964, Summary of the geology of Florida and a guidebook to the classic exposures: Florida Geological Survey Special Publication 5, revised, 312 p.

Schmidt, W., 1984, Neogene stratigraphy and geologic history of the Apalachicola Embayment: Florida Geological Survey Bulletin 58, 146 p.

Scott, T.M., 1981a, The paleo-extent of the Miocene Hawthorn Formation in peninsular Florida [abs.]: Florida Scientist, v. 44, Supplement 1, p. 42.

, 1981b, The Hawthorn Formation of North Florida: Southeastern Geological Society, Field Conference Guidebook, v. 23, p. 15-23.

, 1988, The lithostratigraphy of the Hawthorn Group (Miocene) of Florida: Florida Geological Survey Bulletin 59, 148 p.

, 1991, A geological overview, in Scott, T.M., Lloyd, J.M., and Maddox, G.L., eds., Florida's ground-water quality monitoring program, hydrogeologic framework: Florida Geological Survey Special Publication 32, 97 p.

, 1992, Geologic map of Lake County, Florida: Florida Geological Survey Open-File Map Series 9, scale 1:126,720.

, 1993a, Geologic map of Orange County, Florida: Florida Geological Survey OpenFile Map Series 47, scale 1:126,720.

, 1993b, Geologic map of Osceola County, Florida: Florida Geological Survey OpenFile Map Series 48, scale 1:126,720. 
, 1997, Miocene to Holocene history of Florida, in Randazzo, A.F. and Jones, D.S., eds., The geology of Florida: Gainesville, University Press of Florida, p. 57-67.

, 2001, Text to accompany the geologic map of Florida: Florida Geological Survey Open-File Report 80, 29 p.

Scott, T.M., and Campbell, K.M., 1993, Geologic map of Hardee County, Florida: Florida Geological Survey Open-File Map Series 51, Scale 1:126,760.

Scott, T.M., Campbell, K.M., Rupert, F.R., Arthur, J.A., Green, R.C., Means, G.H., Missimer, T.M., Lloyd, J.M., Yon, J.W., and Duncan, J.G., 2001, Geologic map of Florida: Florida Geological Survey Map Series 146, scale 1:750,000.

Scott, T.M., Means, G.H., Means, R.C., and Meegan R.P., 2002, First magnitude springs of Florida: Florida Geological Survey Open-File Report 85, 138 p.

Scott, T.M., and Allmon, W., eds., 1990, Plio-Pleistocene stratigraphy and paleontology of south Florida: Southeastern Geological Society Field Trip Guidebook 31, unpaginated.

Scott, T.M., and Wingard, G.L., 1995, Facies, fossils, and time - A discussion of the litho- and biostratigraphic problems in the Plio-Pleistocene sediments in southern Florida: in Scott, T.M., 1995, compiler, Stratigraphy and paleontology of the Plio-Pleistocene shell beds, southwest Florida: Southeastern Geological Society Guidebook no. 35, unpaginated.

Sellards, E.H., 1915, The pebble phosphates of Florida: Florida Geological Survey Seventh Annual Report, p. 25-117.

Southeastern Geological Society Ad Hoc Committee on Florida Hydrostratigraphic Unit Definition, 1986, Hydrogeological units of Florida: Florida Geological Survey Special Publication 28, 8 p.

Swancar, A., and C.B. Hutchinson, 1995. Chemical and Isotopic Composition and Potential for Contamination of Water in the Upper Floridan Aquifer, West-Central Florida, 1986-89: U.S. Geological Survey Water-Supply Paper 2409, 68 p.

Upchurch, S.B., Strom, R.N., and Nuckels, M.G., 1982, Silicification of Miocene rocks from central Florida, in Scott, T.M., and Upchurch, S.B., eds., Miocene of the southeastern United States: Florida Geological Survey Special Publication 25, p. 251-284.

Upchurch, S.B., Scott, T.M., Alfieri, M.C., and Dobecki, T.L., 2015, Shallow depressions in the Florida coastal plain: Karst and pseudokarst, in Doctor, D.H., Land, L., Stephenson, J.B., eds., 2015, Proceedings of the Fourteenth Multidisciplinary Conference on Sinkholes and the Engineering and Environmental Impacts of Karst, NCKRI Symposium 5, Rochester, Minnesota: Carlsbad, New Mexico: National Cave and Karst Research Institute, p. 231-239.

U.S. Geological Survey, 1979, 1:100,000-scale metric topographic map of the Kissimmee Quadrangle, Florida: Reston, U.S. Geological Survey, 1 sheet. 
Vernon, R.O., 1951, Geology of Citrus and Levy Counties, Florida: Florida Geological Survey Bulletin 33, 256 p.

Waltham, T., Bell, F., and Culshaw, M., 2005, Sinkholes and subsidence, karst and cavernous rocks in engineering and construction: Chichester, Praxis Publishing Ltd., 382 p.

Webb, S.D., and Crissinger, D.B., 1983, Stratigraphy and vertebrate paleontology of the central and southern phosphate districts of Florida, in The Central Florida Phosphate District - Field Trip Guidebook, Geological Society of America, Southeastern Section Annual Meeting, p. 2872.

White, W.A., 1970, The geomorphology of the Florida peninsula: Florida Geological Survey Bulletin 51, $164 \mathrm{p}$.

Williams, C.P., Burdette, K.E., Green, R.C., Bassett, S.W., Flor, A.D., and Paul, D.T., 2011, Text to accompany geologic map of the eastern portion of the U.S.G.S. Inverness $30 \times 60$ minute quadrangle, central Florida: Florida Geological Survey Open File Report 96, 40 p.

Williams, C.P., Green, R.C., Bassett, S.W., Hannon, L.M., and Flor, A.D., 2012, Geologic map of the western portion of the U.S.G.S. Inverness 30 x 60 minute quadrangle, central Florida: Florida Geological Survey Open-File Map Series 97, scale 1:100,000, 3 plates.

Williams, C.P., and Green, R.C., 2012, Text to accompany geologic map of the western portion of the U.S.G.S. Inverness 30 x 60 minute quadrangle, central Florida: Florida Geological Survey Open File Report 98, 40 p.

Williams, C.P., Scott, T.M., Upchurch, S.B., Hannon, L.M., and Paul, D.T. (in preparation), Florida Geomorphology: Florida Geological Survey Bulletin 72.

Williams, K.E., Nicol, D., and Randazzo, A.F., 1977, The geology of the western part of Alachua County, Florida: Florida Geological Survey Report of Investigation 85, 97 p.

Winston, G.O., 1971, Regional structure, stratigraphy and oil possibilities of the South Florida Basin: Gulf Coast Association of Geological Societies Transactions, v. 21, p. 15-29. 


\section{ACKNOWLEDGEMENTS}

The authors extend many thanks to the personnel that assisted with access to land holdings: Steven R. Miller with the St. Johns River Water Management District's Bureau of Land Management was instrumental in granting the Special Use Authorization permit that allowed the FGS access for field reconnaissance and drilling on SJRWMD properties. We would like to thank Jefferey B. Davis, Lance D. Hart and Graham Williams with SJRWMD for assisting with access to Hal Scott Preserve for the purpose of drilling. Thank you to Chad Allison, Land Steward, Upper Lakes Region (South Florida Water Management District), for help attaining permits for the Rough Island core drill site. A special thanks to Wink Winkler from E.R. Jahna Industries, Inc., and Marc Hurst with Independent Geological Services, Inc. for access to some of their respective mining operations along the Lake Wales Ridge that provided valuable insight into the Cypresshead Formation.

LiDAR coverage provided by Richard Helfst from the Lake County GIS Services Division of Information Technology, was extremely valuable in developing our geologic maps and our top of rock modeling.

Nicholas Bloodworth, Ken Campbell, Bob Cleveland, Jesse Hurd, David Paul, Guy Richardson, and Eric Thomas provided field support for drilling operations. Levi Hannon, Charles Boyd, Katie White, and Brianne Apolinar worked to make sure all wells were appropriately located using every piece of archived well location information that could be found. Livia Nason helped with R programming and some of the modeling. Thank you to Alan Baker, Clint Kromhout, Harley Means, and David Paul who reviewed, discussed, and edited the product. Tom Scott continues to be an asset to geologic mapping in Florida and the ongoing work to revise the state's geomorphic map. This geologic map was funded in part by the Florida Geological Survey of the Florida Department of Environmental Protection and by the United States Geological Survey National Cooperative Geologic Mapping Program under assistance award number G17AC00309 in Federal fiscal year 2017. 


\section{APPENDIX A: FLORIDA GEOLOGICAL SURVEY WELLS UTILIZED FOR STUDY}

This table lists FGS wells within the boundaries of the USGS Kissimmee 30 x 60 minute quadrangle utilized for the top of rock model and/or geologic mapping. Due to graphical constraints, not all wells will appear on Plate 1 of OFMS 110. The first 47 wells in the table were utilized for geologic cross-sections and appear on Plates 1 and 2 of OFMS 110.

\begin{tabular}{|c|c|c|c|c|c|c|c|c|}
\hline $\begin{array}{c}\text { Map } \\
\text { ID }\end{array}$ & $\begin{array}{c}\text { Well } \\
\text { Label }\end{array}$ & $\begin{array}{c}\text { Data } \\
\text { Source }\end{array}$ & $\begin{array}{c}\text { Sample } \\
\text { Type } \\
\end{array}$ & Latitude & Longitude & 24K Quad & $\begin{array}{c}\text { Elevation } \\
\text { (ft.) }\end{array}$ & $\begin{array}{c}\text { Total } \\
\text { Depth (ft.) } \\
\end{array}$ \\
\hline 1 & W-616 & FGS & Cuttings & 28.07974 & -81.67647 & WINTER HAVEN & 152 & 592 \\
\hline 2 & W-872 & FGS & Cuttings & 28.06474 & -81.79036 & AUBURNDALE & 169 & 616 \\
\hline 3 & W-2133 & FGS & Cuttings & 28.25692 & -81.70239 & LAKE LOUISA SW & 130 & 120 \\
\hline 4 & W-2696 & FGS & Cuttings & 28.43217 & -81.40483 & LAKE JESSAMINE & 94 & 275 \\
\hline 5 & W-4290 & FGS & Cuttings & 28.35363 & -81.10119 & NARCOOSSEE SE & 72 & 640 \\
\hline 6 & W-4412 & FGS & Cuttings & 28.07558 & -81.73147 & WINTER HAVEN & 129 & 152 \\
\hline 7 & W-4705 & FGS & Cuttings & 28.41806 & -81.31750 & PINE CASTLE & 84 & 453 \\
\hline 8 & W-4919 & FGS & Cuttings & 28.19895 & -81.64227 & GUM LAKE & 181 & 486 \\
\hline 9 & W-5055 & FGS & Cuttings & 28.38278 & -81.82333 & LAKE NELLIE & 117 & 192 \\
\hline 10 & W-5470 & FGS & Cuttings & 28.25918 & -81.82480 & POYNER & 129 & 232 \\
\hline 11 & W-6040 & FGS & Cuttings & 28.42501 & -81.12534 & NARCOOSSEE NW & 72 & 710 \\
\hline 12 & W-6476 & FGS & Cuttings & 28.36174 & -81.40452 & KISSIMMEE & 84 & 432 \\
\hline 13 & W-8393 & FGS & Cuttings & 28.44556 & -81.66480 & LAKE LOUISA & 128 & 456 \\
\hline 14 & W-10373 & FGS & Cuttings & 28.41415 & -81.18634 & NARCOOSSEE NW & 69 & 325 \\
\hline 15 & W-10665 & FGS & Cuttings & 28.43107 & -81.58015 & WINDERMERE & 100 & 340 \\
\hline 16 & W-11289 & FGS & Cuttings & 28.34815 & -81.67556 & LAKE LOUISA SW & 148 & 213 \\
\hline 17 & W-11315 & FGS & Cuttings & 28.29733 & -81.66731 & LAKE LOUISA SW & 160 & 350 \\
\hline 18 & W-11415 & FGS & Cuttings & 28.25000 & -81.49970 & LAKE TOHOPEKALIGA & 62 & 400 \\
\hline 19 & W-11685 & FGS & Cuttings & 28.03419 & -81.04451 & HOLOPAW SE & 69 & 520 \\
\hline 20 & W-11954 & FGS & Cuttings & 28.08891 & -81.07463 & HOLOPAW SE & 73 & 380 \\
\hline 21 & W-12313 & FGS & Cuttings & 28.31944 & -81.39500 & KISSIMMEE & 73 & 415 \\
\hline 22 & W-12495 & FGS & Cuttings & 28.06222 & -81.61944 & DUNDEE & 174 & 552 \\
\hline 23 & W-12947 & FGS & Cuttings & 28.12098 & -81.63165 & WINTER HAVEN & 149 & 565 \\
\hline 24 & W-13055 & FGS & Core & 28.12250 & -81.81500 & AUBURNDALE & 163 & 135 \\
\hline 25 & W-13061 & FGS & Core & 28.31250 & -81.83500 & POYNER & 148 & 85 \\
\hline 26 & W-13676 & FGS & Core & 28.27695 & -81.08062 & NARCOOSSEE SE & 80 & 342 \\
\hline 27 & W-14080 & FGS & Cuttings & 28.42634 & -81.51236 & WINDERMERE & 103 & 190 \\
\hline 28 & W-14247 & FGS & Cuttings & 28.44111 & -81.76111 & LAKE NELLIE & 108 & 387 \\
\hline 29 & W-14251 & FGS & Cuttings & 28.40251 & -81.68623 & LAKE LOUISA & 127 & 425 \\
\hline 30 & W-14389 & FGS & Cuttings & 28.18264 & -81.83061 & POLK CITY & 134 & 315 \\
\hline 31 & W-14416 & FGS & Cuttings & 28.43991 & -81.86439 & LAKE NELLIE & 107 & 266 \\
\hline 32 & W-14421 & FGS & Cuttings & 28.26806 & -81.23583 & NARCOOSSEE & 74 & 526 \\
\hline 33 & W-14525 & FGS & Cuttings & 28.47194 & -81.41722 & LAKE JESSAMINE & 96 & 188 \\
\hline 34 & W-14880 & FGS & Core & 28.45484 & -81.92549 & BAY LAKE & 100 & 374 \\
\hline 35 & W-14938 & FGS & Cuttings & 28.13726 & -81.08454 & HOLOPAW & 73 & 790 \\
\hline 36 & W-15053 & FGS & Cuttings & 28.43368 & -81.47594 & LAKE JESSAMINE & 99 & 310 \\
\hline 37 & W-15600 & FGS & Core & 28.25890 & -81.91563 & ROCK RIDGE & 117 & 60 \\
\hline 38 & W-15673 & FGS & Cuttings & 28.06902 & -81.49716 & LAKE HATCHINEHA & 104 & 502 \\
\hline 39 & W-15839 & FGS & Cuttings & 28.06482 & -81.55223 & DUNDEE & 89 & 1410 \\
\hline 40 & W-16037 & FGS & Cuttings & 28.25167 & -81.64861 & LAKE LOUISA SW & 198 & 570 \\
\hline 41 & W-16953 & FGS & Cuttings & 28.07252 & -81.27951 & CYPRESS LAKE & 59 & 610 \\
\hline 42 & W-17020 & FGS & Cuttings & 28.26639 & -81.56583 & INTERCESSION CITY & 89 & 280 \\
\hline 43 & W-17140 & FGS & Cuttings & 28.09307 & -81.11645 & HOLOPAW SE & 81 & 1030 \\
\hline 44 & W-17142 & FGS & Cuttings & 28.14001 & -81.35062 & SAINT CLOUD SOUTH & 54 & 980 \\
\hline 45 & W-17429 & FGS & Cuttings & 28.25618 & -81.38307 & KISSIMMEE & 64 & 380 \\
\hline 46 & W-19695 & FGS & Core & 28.074542 & -81.350820 & CYPRESS LAKE & 53 & 412 \\
\hline 47 & W-19697 & FGS & Core & 28.470750 & -81.116889 & NARCOOSSEE NE & 56 & 350 \\
\hline 48 & W-24 & FGS & Cuttings & 28.05566 & -81.97135 & LAKELAND & 211 & 753 \\
\hline 49 & W-88 & FGS & Cuttings & 28.49889 & -81.30479 & PINE CASTLE & 95 & 422 \\
\hline
\end{tabular}


OPEN-FILE REPORT 107

\begin{tabular}{|c|c|c|c|c|c|c|c|c|}
\hline $\begin{array}{l}\text { Map } \\
\text { ID }\end{array}$ & $\begin{array}{c}\text { Well } \\
\text { Label }\end{array}$ & $\begin{array}{c}\text { Data } \\
\text { Source }\end{array}$ & $\begin{array}{c}\text { Sample } \\
\text { Type }\end{array}$ & Latitude & Longitude & 24K Quad & $\begin{array}{c}\text { Elevation } \\
\text { (ft.) }\end{array}$ & $\begin{array}{c}\text { Total } \\
\text { Depth (ft.) }\end{array}$ \\
\hline 50 & W-218 & FGS & Cuttings & 28.42084 & -81.48396 & LAKE JESSAMINE & 96 & 484 \\
\hline 51 & $\mathrm{~W}-275$ & FGS & Cuttings & 28.39230 & -81.82529 & LAKE NELLIE & 113 & 6129 \\
\hline 52 & W-407 & FGS & Cuttings & 28.10383 & -81.71402 & WINTER HAVEN & 133 & 490 \\
\hline 53 & $\mathrm{~W}-448$ & FGS & Cuttings & 28.10002 & -81.96313 & LAKELAND & 157 & 550 \\
\hline 54 & W-458 & FGS & Cuttings & 28.06307 & -81.56674 & DUNDEE & 105 & 600 \\
\hline 55 & $\mathrm{~W}-462$ & FGS & Cuttings & 28.49392 & -81.53481 & WINDERMERE & 126 & 146 \\
\hline 56 & W-697 & FGS & Cuttings & 28.29084 & -81.44646 & KISSIMMEE & 79 & 394 \\
\hline 57 & W-864 & FGS & Cuttings & 28.01677 & -81.73076 & WINTER HAVEN & 164 & 240 \\
\hline 58 & W-951 & FGS & Cuttings & 28.09196 & -81.72285 & WINTER HAVEN & 169 & 555 \\
\hline 59 & W-1016 & FGS & Cuttings & 28.30168 & -81.37257 & SAINT CLOUD NORTH & 74 & 550 \\
\hline 60 & W-1416 & FGS & Cuttings & 28.06058 & -81.61952 & DUNDEE & 168 & 561 \\
\hline 61 & W-1452 & FGS & Cuttings & 28.26140 & -81.30090 & SAINT CLOUD NORTH & 59 & 455 \\
\hline 62 & W-1453 & FGS & Cuttings & 28.37917 & -81.23806 & NARCOOSSEE NW & 69 & 400 \\
\hline 63 & W-1457 & FGS & Cuttings & 28.39084 & -81.52007 & WINDERMERE & 99 & 368.7 \\
\hline 64 & W-1477 & FGS & Cuttings & 28.38556 & -81.16953 & NARCOOSSEE NW & 60 & 310 \\
\hline 65 & W-1518 & FGS & Cuttings & 28.39306 & -81.23111 & NARCOOSSEE NW & 66 & 350 \\
\hline 66 & W-1589 & FGS & Cuttings & 28.03211 & -81.94813 & LAKELAND & 201 & 1111 \\
\hline 67 & W-1664 & FGS & Cuttings & 28.45450 & -81.27023 & PINE CASTLE & 90 & 277 \\
\hline 68 & W-1720 & FGS & Cuttings & 28.23288 & -81.56280 & DAVENPORT & 103 & 202 \\
\hline 69 & W-1752 & FGS & Cuttings & 28.48694 & -81.38472 & LAKE JESSAMINE & 100 & 222 \\
\hline 70 & W-1800 & FGS & Cuttings & 28.06178 & -81.90234 & LAKELAND & 138 & 570 \\
\hline 71 & W-1822 & FGS & Cuttings & 28.44917 & -81.50667 & WINDERMERE & 116 & 560 \\
\hline 72 & W-1833 & FGS & Cuttings & 28.14625 & -81.15286 & ASHTON & 69 & 6510 \\
\hline 73 & W-1835 & FGS & Cuttings & 28.00378 & -81.91636 & LAKELAND & 129 & 1220 \\
\hline 74 & W-1875 & FGS & Cuttings & 28.05952 & -81.79806 & AUBURNDALE & 154 & 701 \\
\hline 75 & W-1882 & FGS & Cuttings & 28.25139 & -81.24211 & NARCOOSSEE & 75 & 470 \\
\hline 76 & W-2003 & FGS & Cuttings & 28.00217 & -81.73108 & WINTER HAVEN & 149 & 677 \\
\hline 77 & W-2040 & FGS & Cuttings & 28.49709 & -81.64575 & LAKE LOUISA & 147 & 660 \\
\hline 78 & W-2163 & FGS & Cuttings & 28.19439 & -81.36611 & SAINT CLOUD SOUTH & 58 & 1995 \\
\hline 79 & W-2647 & FGS & Cuttings & 28.09056 & -81.78750 & AUBURNDALE & 170 & 580 \\
\hline 80 & W-2695 & FGS & Cuttings & 28.10970 & -81.62731 & WINTER HAVEN & 161 & 810 \\
\hline 81 & W-2869 & FGS & Cuttings & 28.16667 & -81.59944 & DAVENPORT & 119 & 575 \\
\hline 82 & W-2925 & FGS & Cuttings & 28.06669 & -81.75480 & AUBURNDALE & 143 & 155 \\
\hline 83 & W-3032 & FGS & Cuttings & 28.46389 & -81.53257 & WINDERMERE & 108 & 347 \\
\hline 84 & W-3072 & FGS & Cuttings & 28.47198 & -81.71575 & LAKE LOUISA & 107 & 320 \\
\hline 85 & W-3107 & FGS & Cuttings & 28.36722 & -81.68194 & LAKE LOUISA SW & 141 & 465 \\
\hline 86 & W-3200 & FGS & Cuttings & 28.01003 & -81.77732 & AUBURNDALE & 146 & 595 \\
\hline 87 & W-3306 & FGS & Cuttings & 28.03660 & -81.71684 & WINTER HAVEN & 144 & 816 \\
\hline 88 & W-3312 & FGS & Cuttings & 28.08446 & -81.99258 & LAKELAND & 228 & 261 \\
\hline 89 & W-3386 & FGS & Cuttings & 28.24752 & -81.29000 & SAINT CLOUD SOUTH & 75 & 692 \\
\hline 90 & W-3751 & FGS & Cuttings & 28.02764 & -81.96534 & LAKELAND & 197 & 716 \\
\hline 91 & W-3799 & FGS & Cuttings & 28.10543 & -81.93500 & LAKELAND & 140 & 602 \\
\hline 92 & W-3830 & FGS & Cuttings & 28.39472 & -81.06806 & NARCOOSSEE NE & 73 & 525 \\
\hline 93 & W-3832 & FGS & Cuttings & 28.39472 & -81.06806 & NARCOOSSEE NE & 73 & 705 \\
\hline 94 & W-3837 & FGS & Cuttings & 28.14893 & -81.89389 & PROVIDENCE & 137 & 93 \\
\hline 95 & W-3839 & FGS & Cuttings & 28.26168 & -81.95564 & ROCK RIDGE & 110 & 108 \\
\hline 96 & W-3841 & FGS & Cuttings & 28.09731 & -81.89132 & LAKELAND & 128 & 72 \\
\hline 97 & W-3851 & FGS & Cuttings & 28.04456 & -81.77047 & AUBURNDALE & 152 & 640 \\
\hline 98 & W-3855 & FGS & Cuttings & 28.40167 & -81.09145 & NARCOOSSEE NE & 73 & 794 \\
\hline 99 & W-3865 & FGS & Cuttings & 28.16263 & -81.88713 & PROVIDENCE & 134 & 488 \\
\hline 100 & W-3883 & FGS & Cuttings & 28.11667 & -81.89855 & LAKELAND & 169 & 1195 \\
\hline 101 & W-4156 & FGS & Cuttings & 28.15198 & -81.89522 & PROVIDENCE & 137 & 570 \\
\hline 102 & W-4184 & FGS & Cuttings & 28.43028 & -81.09479 & NARCOOSSEE NE & 69 & 496 \\
\hline 103 & W-4274 & FGS & Cuttings & 28.44862 & -81.44979 & LAKE JESSAMINE & 95 & 409 \\
\hline 104 & W-4275 & FGS & Cuttings & 28.16640 & -81.79091 & POLK CITY & 140 & 524 \\
\hline 105 & W-4279 & FGS & Cuttings & 28.41612 & -81.09589 & NARCOOSSEE NE & 69 & 593 \\
\hline 106 & W-4313 & FGS & Cuttings & 28.08613 & -81.62897 & WINTER HAVEN & 184 & 575 \\
\hline 107 & W-4353 & FGS & Cuttings & 28.44306 & -81.40000 & LAKE JESSAMINE & 99 & 292 \\
\hline
\end{tabular}


FLORIDA GEOLOGICAL SURVEY

\begin{tabular}{|c|c|c|c|c|c|c|c|c|}
\hline $\begin{array}{l}\text { Map } \\
\text { ID }\end{array}$ & $\begin{array}{c}\text { Well } \\
\text { Label }\end{array}$ & $\begin{array}{c}\text { Data } \\
\text { Source }\end{array}$ & $\begin{array}{c}\text { Sample } \\
\text { Type }\end{array}$ & Latitude & Longitude & 24K Quad & $\begin{array}{c}\text { Elevation } \\
\text { (ft.) }\end{array}$ & $\begin{array}{c}\text { Total } \\
\text { Depth (ft.) }\end{array}$ \\
\hline 108 & W-4493 & FGS & Cuttings & 28.02110 & -81.62520 & WINTER HAVEN & 123 & 180 \\
\hline 109 & W-4642 & FGS & Cuttings & 28.21852 & -81.58546 & DAVENPORT & 109 & 180 \\
\hline 110 & W-4706 & FGS & Cuttings & 28.48083 & -81.47806 & LAKE JESSAMINE & 133 & 411 \\
\hline 111 & W-4748 & FGS & Cuttings & 28.10538 & -81.97683 & LAKELAND & 186 & 200 \\
\hline 112 & W-4775 & FGS & Cuttings & 28.03775 & -81.87609 & LAKELAND & 103 & 200 \\
\hline 113 & W-4989 & FGS & Cuttings & 28.46167 & -81.98214 & BAY LAKE & 96 & 175 \\
\hline 114 & W-4990 & FGS & Cuttings & 28.16863 & -81.73758 & GUM LAKE & 137 & 249 \\
\hline 115 & W-4997 & FGS & Cuttings & 28.42583 & -81.35833 & PINE CASTLE & 94 & 450 \\
\hline 116 & W-5045 & FGS & Cuttings & 28.32687 & -81.80515 & POYNER & 119 & 510 \\
\hline 117 & W-5046 & FGS & Cuttings & 28.22142 & -81.92015 & PROVIDENCE & 125 & 216 \\
\hline 118 & W-5052 & FGS & Cuttings & 28.36751 & -81.64583 & LAKE LOUISA SW & 119 & 114 \\
\hline 119 & W-5121 & FGS & Cuttings & 28.27672 & -81.40598 & KISSIMMEE & 48 & 410 \\
\hline 120 & W-5128 & FGS & Cuttings & 28.40362 & -81.07951 & NARCOOSSEE NE & 74 & 600 \\
\hline 121 & W-5236 & FGS & Cuttings & 28.30661 & -81.40158 & KISSIMMEE & 69 & 340 \\
\hline 122 & W-5324 & FGS & Cuttings & 28.05335 & -81.90842 & LAKELAND & 140 & 866 \\
\hline 123 & W-5353 & FGS & Cuttings & 28.05169 & -81.72675 & WINTER HAVEN & 134 & 305 \\
\hline 124 & W-5471 & FGS & Cuttings & 28.25889 & -81.58056 & INTERCESSION CITY & 109 & 250 \\
\hline 125 & W-5472 & FGS & Cuttings & 28.22196 & -81.84203 & POLK CITY & 129 & 205 \\
\hline 126 & W-5473 & FGS & Cuttings & 28.24517 & -81.72187 & GUM LAKE & 130 & 285 \\
\hline 127 & W-5777 & FGS & Cuttings & 28.49806 & -81.62222 & WINDERMERE & 140 & 460 \\
\hline 128 & W-5802 & FGS & Cuttings & 28.46972 & -81.49806 & LAKE JESSAMINE & 160 & 500 \\
\hline 129 & W-5820 & FGS & Cuttings & 28.11377 & -81.62761 & WINTER HAVEN & 162 & 620 \\
\hline 130 & W-5867 & FGS & Cuttings & 28.45056 & -81.64271 & LAKE LOUISA & 163 & 465 \\
\hline 131 & W-5868 & FGS & Cuttings & 28.47156 & -81.64389 & LAKE LOUISA & 190 & 525 \\
\hline 132 & W-5869 & FGS & Cuttings & 28.26656 & -81.31908 & SAINT CLOUD NORTH & 65 & 630 \\
\hline 133 & W-5875 & FGS & Cuttings & 28.13712 & -81.89953 & PROVIDENCE & 132 & 158 \\
\hline 134 & W-5880 & FGS & Cuttings & 28.34068 & -81.20292 & NARCOOSSEE & 74 & 598 \\
\hline 135 & W-5881 & FGS & Cuttings & 28.38001 & -81.61313 & WINDERMERE & 112 & 380 \\
\hline 136 & W-5892 & FGS & Cuttings & 28.30611 & -81.59747 & INTERCESSION CITY & 115 & 839 \\
\hline 137 & W-5893 & FGS & Cuttings & 28.30712 & -81.67061 & LAKE LOUISA SW & 212 & 610 \\
\hline 138 & W-5925 & FGS & Cuttings & 28.13958 & -81.86962 & POLK CITY & 135 & 531 \\
\hline 139 & W-5926 & FGS & Cuttings & 28.28283 & -81.65214 & LAKE LOUISA SW & 156 & 400 \\
\hline 140 & W-6007 & FGS & Cuttings & 28.42556 & -81.13201 & NARCOOSSEE NW & 62 & 509 \\
\hline 141 & W-6008 & FGS & Cuttings & 28.32898 & -81.59830 & INTERCESSION CITY & 117 & 745 \\
\hline 142 & W-6010 & FGS & Cuttings & 28.45833 & -81.57250 & WINDERMERE & 118 & 430 \\
\hline 143 & W-6075 & FGS & Cuttings & 28.42556 & -81.13923 & NARCOOSSEE NW & 63 & 761 \\
\hline 144 & W-6146 & FGS & Cuttings & 28.42333 & -81.35722 & PINE CASTLE & 93 & 335 \\
\hline 145 & W-6181 & FGS & Cuttings & 28.26806 & -81.67168 & LAKE LOUISA SW & 124 & 435 \\
\hline 146 & W-6182 & FGS & Cuttings & 28.06250 & -81.50500 & DUNDEE & 91 & 670 \\
\hline 147 & W-6183 & FGS & Cuttings & 28.36806 & -81.76230 & POYNER & 119 & 712 \\
\hline 148 & W-6362 & FGS & Cuttings & 28.41222 & -81.49861 & LAKE JESSAMINE & 127 & 391 \\
\hline 149 & W-6370 & FGS & Cuttings & 28.34822 & -81.30944 & SAINT CLOUD NORTH & 74 & 395 \\
\hline 150 & W-6371 & FGS & Cuttings & 28.42584 & -81.13201 & NARCOOSSEE NW & 62 & 515 \\
\hline 151 & W-6372 & FGS & Cuttings & 28.42584 & -81.16534 & NARCOOSSEE NW & 75 & 300 \\
\hline 152 & W-6373 & FGS & Cuttings & 28.37834 & -81.19090 & NARCOOSSEE NW & 67 & 475 \\
\hline 153 & W-6457 & FGS & Cuttings & 28.48000 & -81.02673 & NARCOOSSEE NE & 62 & 495 \\
\hline 154 & W-6474 & FGS & Cuttings & 28.44334 & -81.26035 & PINE CASTLE & 89 & 435 \\
\hline 155 & W-6512 & FGS & Cuttings & 28.47523 & -81.67767 & LAKE LOUISA & 144 & 677 \\
\hline 156 & W-6548 & FGS & Cuttings & 28.42528 & -81.14812 & NARCOOSSEE NW & 65 & 702 \\
\hline 157 & W-6637 & FGS & Cuttings & 28.49167 & -81.57528 & WINDERMERE & 121 & 957 \\
\hline 158 & W-6867 & FGS & Cuttings & 28.42444 & -81.12422 & NARCOOSSEE NE & 70 & 500 \\
\hline 159 & W-6871 & FGS & Cuttings & 28.43704 & -81.43995 & LAKE JESSAMINE & 90 & 241 \\
\hline 160 & W-6892 & FGS & Cuttings & 28.42702 & -81.26270 & PINE CASTLE & 89 & 572 \\
\hline 161 & W-7544 & FGS & Cuttings & 28.39298 & -81.48110 & LAKE JESSAMINE & 121 & 240 \\
\hline 162 & W-7658 & FGS & Core & 28.28511 & -81.58867 & INTERCESSION CITY & 88 & 126.5 \\
\hline 163 & W-7749 & FGS & Cuttings & 28.02252 & -81.97286 & LAKELAND & 168 & 703 \\
\hline 164 & W-7932 & FGS & Cuttings & 28.00433 & -81.69604 & WINTER HAVEN & 174 & 772 \\
\hline 165 & W-8380 & FGS & Cuttings & 28.07186 & -81.95184 & LAKELAND & 168 & 920 \\
\hline
\end{tabular}


OPEN-FILE REPORT 107

\begin{tabular}{|c|c|c|c|c|c|c|c|c|}
\hline $\begin{array}{l}\text { Map } \\
\text { ID }\end{array}$ & $\begin{array}{c}\text { Well } \\
\text { Label }\end{array}$ & $\begin{array}{c}\text { Data } \\
\text { Source }\end{array}$ & $\begin{array}{c}\text { Sample } \\
\text { Type }\end{array}$ & Latitude & Longitude & 24K Quad & $\begin{array}{c}\text { Elevation } \\
\text { (ft.) }\end{array}$ & $\begin{array}{c}\text { Total } \\
\text { Depth (ft.) }\end{array}$ \\
\hline 166 & W-8388 & FGS & Cuttings & 28.44416 & -81.47706 & LAKE JESSAMINE & 121 & 464 \\
\hline 167 & W-8497 & FGS & Cuttings & 28.32723 & -81.41618 & KISSIMMEE & 85 & 1200 \\
\hline 168 & W-8558 & FGS & Cuttings & 28.40466 & -81.39020 & LAKE JESSAMINE & 86 & 367 \\
\hline 169 & W-8595 & FGS & Cuttings & 28.11253 & -81.88314 & LAKELAND & 165 & 1201 \\
\hline 170 & W-8723 & FGS & Cuttings & 28.40028 & -81.52667 & WINDERMERE & 110 & 350 \\
\hline 171 & W-10248 & FGS & Cuttings & 28.02241 & -81.61210 & DUNDEE & 128 & 755 \\
\hline 172 & W-10254 & FGS & Core & 28.09826 & -81.90139 & LAKELAND & 132 & 1479 \\
\hline 173 & W-10365 & FGS & Cuttings & 28.49723 & -81.51535 & WINDERMERE & 114 & 200 \\
\hline 174 & W-10508 & FGS & Cuttings & 28.42750 & -81.56627 & WINDERMERE & 99 & 500 \\
\hline 175 & W-10537 & FGS & Cuttings & 28.32529 & -81.46609 & KISSIMMEE & 80 & 330 \\
\hline 176 & W-10580 & FGS & Cuttings & 28.10630 & -81.64863 & WINTER HAVEN & 128 & 230 \\
\hline 177 & W-10586 & FGS & Cuttings & 28.29722 & -81.23583 & NARCOOSSEE & 75 & 375 \\
\hline 178 & W-10587 & FGS & Cuttings & 28.32616 & -81.23611 & NARCOOSSEE & 64 & 259 \\
\hline 179 & W-10592 & FGS & Cuttings & 28.06228 & -81.99235 & LAKELAND & 140 & 642 \\
\hline 180 & W-10679 & FGS & Cuttings & 28.07692 & -81.83361 & AUBURNDALE & 144 & 150 \\
\hline 181 & W-10696 & FGS & Cuttings & 28.26731 & -81.43098 & KISSIMMEE & 53 & 336 \\
\hline 182 & W-10774 & FGS & Cuttings & 28.47967 & -81.03878 & NARCOOSSEE NE & 67 & 136.5 \\
\hline 183 & W-10775 & FGS & Cuttings & 28.47407 & -81.03709 & NARCOOSSEE NE & 68 & 131.2 \\
\hline 184 & W-10776 & FGS & Cuttings & 28.47967 & -81.03878 & NARCOOSSEE NE & 67 & 147.5 \\
\hline 185 & W-10777 & FGS & Cuttings & 28.47967 & -81.03878 & NARCOOSSEE NE & 67 & 480 \\
\hline 186 & W-10778 & FGS & Cuttings & 28.47406 & -81.03710 & NARCOOSSEE NE & 68 & 7119 \\
\hline 187 & W-10784 & FGS & Cuttings & 28.48112 & -81.20924 & NARCOOSSEE NW & 79 & 475 \\
\hline 188 & W-10799 & FGS & Cuttings & 28.39464 & -81.57836 & WINDERMERE & 93 & 400 \\
\hline 189 & W-10851 & FGS & Cuttings & 28.21921 & -81.69410 & GUM LAKE & 129 & 465 \\
\hline 190 & W-10899 & FGS & Cuttings & 28.33833 & -81.59299 & INTERCESSION CITY & 108 & 300 \\
\hline 191 & W-10939 & FGS & Cuttings & 28.34751 & -81.23368 & NARCOOSSEE & 64 & 470 \\
\hline 192 & W-11040 & FGS & Cuttings & 28.25139 & -81.46602 & KISSIMMEE & 69 & 255 \\
\hline 193 & W-11173 & FGS & Cuttings & 28.49130 & -81.27599 & PINE CASTLE & 84 & 540 \\
\hline 194 & W-11207 & FGS & Cuttings & 28.38375 & -81.53268 & WINDERMERE & 93 & 393 \\
\hline 195 & W-11217 & FGS & Cuttings & 28.15344 & -81.81192 & POLK CITY & 181 & 602 \\
\hline 196 & W-11230 & FGS & Cuttings & 28.20107 & -81.63540 & GUM LAKE & 155 & 740 \\
\hline 197 & W-11290 & FGS & Cuttings & 28.22258 & -81.64867 & GUM LAKE & 178 & 310 \\
\hline 198 & W-11296 & FGS & Cuttings & 28.20818 & -81.63195 & GUM LAKE & 145 & 400 \\
\hline 199 & W-11300 & FGS & Cuttings & 28.34613 & -81.63404 & LAKE LOUISA SW & 124 & 420 \\
\hline 200 & W-11304 & FGS & Cuttings & 28.35399 & -81.63220 & LAKE LOUISA SW & 112 & 197 \\
\hline 201 & W-11307 & FGS & Cuttings & 28.27084 & -81.19293 & NARCOOSSEE & 66 & 424 \\
\hline 202 & W-11332 & FGS & Cuttings & 28.19361 & -81.78110 & POLK CITY & 130 & 550 \\
\hline 203 & W-11369 & FGS & Cuttings & 28.11880 & -81.36992 & CYPRESS LAKE & 60 & 620 \\
\hline 204 & W-11416 & FGS & Cuttings & 28.22318 & -81.48307 & LAKE TOHOPEKALIGA & 70 & 390 \\
\hline 205 & W-11417 & FGS & Cuttings & 28.25133 & -81.49569 & KISSIMMEE & 68 & 400 \\
\hline 206 & W-11420 & FGS & Cuttings & 28.16548 & -81.44812 & LAKE TOHOPEKALIGA & 58 & 400 \\
\hline 207 & W-11478 & FGS & Cuttings & 28.34352 & -81.58354 & INTERCESSION CITY & 92 & 367 \\
\hline 208 & W-11517 & FGS & Cuttings & 28.32725 & -81.49524 & KISSIMMEE & 71 & 405 \\
\hline 209 & W-11525 & FGS & Cuttings & 28.15007 & -81.64865 & GUM LAKE & 134 & 462 \\
\hline 210 & W-11558 & FGS & Cuttings & 28.33940 & -81.63214 & LAKE LOUISA SW & 104 & 360 \\
\hline 211 & W-11628 & FGS & Cuttings & 28.48361 & -81.19118 & NARCOOSSEE NW & 85 & 280 \\
\hline 212 & W-11630 & FGS & Cuttings & 28.48833 & -81.20295 & NARCOOSSEE NW & 82 & 340 \\
\hline 213 & W-11674 & FGS & Cuttings & 28.35385 & -81.64884 & LAKE LOUISA SW & 112 & 375 \\
\hline 214 & W-11676 & FGS & Cuttings & 28.31167 & -81.66583 & LAKE LOUISA SW & 201 & 480 \\
\hline 215 & W-11682 & FGS & Cuttings & 28.28691 & -81.35527 & SAINT CLOUD NORTH & 64 & 215 \\
\hline 216 & W-11731 & FGS & Cuttings & 28.42699 & -81.83089 & LAKE NELLIE & 118 & 365 \\
\hline 217 & W-11748 & FGS & Cuttings & 28.41345 & -81.45000 & LAKE JESSAMINE & 90 & 500 \\
\hline 218 & W-11782 & FGS & Cuttings & 28.23882 & -81.20694 & ASHTON & 66 & 241 \\
\hline 219 & W-11895 & FGS & Cuttings & 28.17997 & -81.44822 & LAKE TOHOPEKALIGA & 68 & 260 \\
\hline 220 & W-11913 & FGS & Cuttings & 28.33944 & -81.52246 & INTERCESSION CITY & 86 & 385 \\
\hline 221 & W-11915 & FGS & Cuttings & 28.26278 & -81.38155 & KISSIMMEE & 60 & 246 \\
\hline 222 & W-12001 & FGS & Cuttings & 28.49028 & -81.48424 & LAKE JESSAMINE & 151 & 492 \\
\hline 223 & W-12007 & FGS & Cuttings & 28.37389 & -81.49969 & KISSIMMEE & 106 & 905 \\
\hline
\end{tabular}


FLORIDA GEOLOGICAL SURVEY

\begin{tabular}{|c|c|c|c|c|c|c|c|c|}
\hline $\begin{array}{l}\text { Map } \\
\text { ID }\end{array}$ & $\begin{array}{c}\text { Well } \\
\text { Label }\end{array}$ & $\begin{array}{c}\text { Data } \\
\text { Source }\end{array}$ & $\begin{array}{c}\text { Sample } \\
\text { Type }\end{array}$ & Latitude & Longitude & 24K Quad & $\begin{array}{c}\text { Elevation } \\
\text { (ft.) }\end{array}$ & $\begin{array}{c}\text { Total } \\
\text { Depth (ft.) }\end{array}$ \\
\hline 224 & W-12008 & FGS & Cuttings & 28.19621 & -81.17664 & ASHTON & 76 & 660 \\
\hline 225 & W-12070 & FGS & Cuttings & 28.12236 & -81.98920 & LAKELAND & 170 & 410 \\
\hline 226 & W-12254 & FGS & Cuttings & 28.35984 & -81.31161 & SAINT CLOUD NORTH & 75 & 330 \\
\hline 227 & W-12269 & FGS & Cuttings & 28.12007 & -81.59276 & DUNDEE & 122 & 400 \\
\hline 228 & W-12356 & FGS & Cuttings & 28.31084 & -81.46603 & KISSIMMEE & 75 & 435 \\
\hline 229 & W-12479 & FGS & Cuttings & 28.32906 & -81.35186 & SAINT CLOUD NORTH & 76 & 689 \\
\hline 230 & W-12792 & FGS & Cuttings & 28.38019 & -81.18996 & NARCOOSSEE NW & 67 & 419 \\
\hline 231 & W-12805 & FGS & Cuttings & 28.38195 & -81.91452 & BAY LAKE & 104 & 200 \\
\hline 232 & W-12871 & FGS & Cuttings & 28.37059 & -81.16945 & NARCOOSSEE & 67 & 410 \\
\hline 233 & W-12883 & FGS & Cuttings & 28.33749 & -81.53842 & INTERCESSION CITY & 89 & 336 \\
\hline 234 & W-12899 & FGS & Cuttings & 28.43834 & -81.50646 & WINDERMERE & 126 & 1013 \\
\hline 235 & W-13048 & FGS & Core & 28.31000 & -81.68139 & LAKE LOUISA SW & 130 & 100 \\
\hline 236 & W-13050 & FGS & Core & 28.20111 & -81.99167 & PROVIDENCE & 118 & 48 \\
\hline 237 & W-13052 & FGS & Core & 28.15861 & -81.68917 & GUM LAKE & 135 & 112 \\
\hline 238 & W-13053 & FGS & Core & 28.16611 & -81.73722 & GUM LAKE & 132 & 99 \\
\hline 239 & W-13054 & FGS & Core & 28.15639 & -81.89833 & PROVIDENCE & 136 & 72 \\
\hline 240 & W-13056 & FGS & Core & 28.17778 & -81.79917 & POLK CITY & 154 & 96 \\
\hline 241 & W-13059 & FGS & Core & 28.20972 & -81.78778 & POLK CITY & 130 & 105 \\
\hline 242 & W-13060 & FGS & Core & 28.22139 & -81.82167 & POLK CITY & 129 & 77 \\
\hline 243 & W-13063 & FGS & Core & 28.45810 & -81.92725 & BAY LAKE & 98 & 87.8 \\
\hline 244 & W-13065 & FGS & Core & 28.18000 & -81.65222 & GUM LAKE & 139 & 160 \\
\hline 245 & W-13068 & FGS & Core & 28.16778 & -81.96806 & PROVIDENCE & 126 & 69 \\
\hline 246 & W-13147 & FGS & Cuttings & 28.44121 & -81.71531 & LAKE LOUISA & 127 & 150 \\
\hline 247 & W-13162 & FGS & Cuttings & 28.45614 & -81.59934 & WINDERMERE & 95 & 340 \\
\hline 248 & W-13287 & FGS & Cuttings & 28.44751 & -81.44007 & LAKE JESSAMINE & 87 & 6192 \\
\hline 249 & W-13323 & FGS & Cuttings & 28.45556 & -81.74833 & LAKE LOUISA & 110 & 337 \\
\hline 250 & W-13340 & FGS & Cuttings & 28.02238 & -81.67751 & WINTER HAVEN & 131 & 151 \\
\hline 251 & W-13422 & FGS & Cuttings & 28.37044 & -81.25250 & SAINT CLOUD NORTH & 80 & 647 \\
\hline 252 & W-13451 & FGS & Cuttings & 28.48361 & -81.77667 & LAKE NELLIE & 118 & 350 \\
\hline 253 & W-13453 & FGS & Cuttings & 28.07849 & -81.65529 & WINTER HAVEN & 147 & 460 \\
\hline 254 & W-13547 & FGS & Core & 28.20833 & -81.23667 & ASHTON & 76 & 580 \\
\hline 255 & W-13550 & FGS & Cuttings & 28.37044 & -81.25250 & SAINT CLOUD NORTH & 80 & 330 \\
\hline 256 & W-13794 & FGS & Core & 28.28485 & -81.37845 & KISSIMMEE & 62 & 227 \\
\hline 257 & W-13865 & FGS & Cuttings & 28.47018 & -81.76524 & LAKE NELLIE & 138 & 355 \\
\hline 258 & W-13893 & FGS & Cuttings & 28.16182 & -81.24505 & ASHTON & 67 & 574 \\
\hline 259 & W-14031 & FGS & Cuttings & 28.48333 & -81.74863 & LAKE LOUISA & 96 & 250 \\
\hline 260 & W-14032 & FGS & Cuttings & 28.23889 & -81.25000 & ASHTON & 68 & 416 \\
\hline 261 & W-14033 & FGS & Core & 28.49958 & -81.91395 & BAY LAKE & 99 & 205 \\
\hline 262 & W-14070 & FGS & Cuttings & 28.20001 & -81.24090 & ASHTON & 67 & 630 \\
\hline 263 & W-14079 & FGS & Cuttings & 28.36889 & -81.59919 & INTERCESSION CITY & 98 & 200 \\
\hline 264 & W-14151 & FGS & Cuttings & 28.33398 & -81.49042 & KISSIMMEE & 83 & 542 \\
\hline 265 & W-14156 & FGS & Cuttings & 28.36794 & -81.50095 & INTERCESSION CITY & 104 & 250 \\
\hline 266 & W-14235 & FGS & Cuttings & 28.33135 & -81.58532 & INTERCESSION CITY & 106 & 300 \\
\hline 267 & W-14237 & FGS & Cuttings & 28.48954 & -81.86518 & LAKE NELLIE & 108 & 261 \\
\hline 268 & W-14249 & FGS & Cuttings & 28.46643 & -81.83654 & LAKE NELLIE & 117 & 365 \\
\hline 269 & W-14250 & FGS & Cuttings & 28.13557 & -81.95369 & PROVIDENCE & 157 & 618 \\
\hline 270 & W-14256 & FGS & Cuttings & 28.44139 & -81.69889 & LAKE LOUISA & 102 & 496 \\
\hline 271 & W-14309 & FGS & Cuttings & 28.28895 & -81.22664 & NARCOOSSEE & 75 & 400 \\
\hline 272 & W-14394 & FGS & Cuttings & 28.22621 & -81.48586 & LAKE TOHOPEKALIGA & 73 & 450 \\
\hline 273 & W-14408 & FGS & Cuttings & 28.42508 & -81.86426 & LAKE NELLIE & 109 & 232 \\
\hline 274 & W-14410 & FGS & Cuttings & 28.49571 & -81.80398 & LAKE NELLIE & 113 & 350 \\
\hline 275 & W-14422 & FGS & Cuttings & 28.47690 & -81.83630 & LAKE NELLIE & 121 & 235 \\
\hline 276 & W-14430 & FGS & Cuttings & 28.38556 & -81.31806 & PINE CASTLE & 71 & 425 \\
\hline 277 & W-14455 & FGS & Cuttings & 28.45095 & -81.29014 & PINE CASTLE & 87 & 390 \\
\hline 278 & W-14555 & FGS & Cuttings & 28.09189 & -81.28389 & CYPRESS LAKE & 66 & 470 \\
\hline 279 & W-14559 & FGS & Cuttings & 28.09328 & -81.26482 & CYPRESS LAKE & 61 & 400 \\
\hline 280 & W-14603 & FGS & Cuttings & 28.35464 & -81.56335 & INTERCESSION CITY & 95 & 500 \\
\hline 281 & W-14649 & FGS & Cuttings & 28.22366 & -81.30139 & SAINT CLOUD SOUTH & 74 & 710 \\
\hline
\end{tabular}


OPEN-FILE REPORT 107

\begin{tabular}{|c|c|c|c|c|c|c|c|c|}
\hline $\begin{array}{l}\text { Map } \\
\text { ID }\end{array}$ & $\begin{array}{c}\text { Well } \\
\text { Label }\end{array}$ & $\begin{array}{c}\text { Data } \\
\text { Source }\end{array}$ & $\begin{array}{c}\text { Sample } \\
\text { Type }\end{array}$ & Latitude & Longitude & 24K Quad & $\begin{array}{c}\text { Elevation } \\
\text { (ft.) }\end{array}$ & $\begin{array}{c}\text { Total } \\
\text { Depth (ft.) }\end{array}$ \\
\hline 282 & W-14650 & FGS & Cuttings & 28.45585 & -81.81456 & LAKE NELLIE & 112 & 395 \\
\hline 283 & W-14819 & FGS & Cuttings & 28.49941 & -81.69896 & LAKE LOUISA & 122 & 480 \\
\hline 284 & W-14942 & FGS & Cuttings & 28.16370 & -81.24741 & ASHTON & 74 & 635 \\
\hline 285 & W-15045 & FGS & Cuttings & 28.13834 & -81.07725 & HOLOPAW & 77 & 275 \\
\hline 286 & W-15090 & FGS & Cuttings & 28.48140 & -81.20916 & NARCOOSSEE NW & 79 & 327 \\
\hline 287 & W-15157 & FGS & Cuttings & 28.15101 & -81.41504 & LAKE TOHOPEKALIGA & 71 & 538 \\
\hline 288 & W-15302 & FGS & Cuttings & 28.12833 & -81.46278 & LAKE TOHOPEKALIGA & 63 & 497 \\
\hline 289 & W-15308 & FGS & Cuttings & 28.36566 & -81.51177 & INTERCESSION CITY & 106 & 590 \\
\hline 290 & W-15313 & FGS & Cuttings & 28.38101 & -81.51852 & WINDERMERE & 101 & 645 \\
\hline 291 & W-15338 & FGS & Cuttings & 28.44137 & -81.79804 & LAKE NELLIE & 123 & 400 \\
\hline 292 & W-15360 & FGS & Cuttings & 28.19451 & -81.26833 & SAINT CLOUD SOUTH & 75 & 460 \\
\hline 293 & W-15382 & FGS & Cuttings & 28.07750 & -81.67194 & WINTER HAVEN & 132 & 220 \\
\hline 294 & W-15402 & FGS & Cuttings & 28.08970 & -81.08952 & HOLOPAW SE & 76 & 840 \\
\hline 295 & W-15403 & FGS & Cuttings & 28.09165 & -81.07930 & HOLOPAW SE & 75 & 790 \\
\hline 296 & W-15404 & FGS & Cuttings & 28.09750 & -81.09633 & HOLOPAW SE & 77 & 820 \\
\hline 297 & W-15407 & FGS & Cuttings & 28.26675 & -81.51628 & INTERCESSION CITY & 65 & 227 \\
\hline 298 & W-15469 & FGS & Cuttings & 28.40860 & -81.46178 & LAKE JESSAMINE & 92 & 450 \\
\hline 299 & W-15470 & FGS & Cuttings & 28.41332 & -81.25473 & PINE CASTLE & 88 & 546 \\
\hline 300 & W-15545 & FGS & Cuttings & 28.36973 & -81.34673 & SAINT CLOUD NORTH & 81 & 300 \\
\hline 301 & W-15569 & FGS & Core & 28.41917 & -81.95536 & BAY LAKE & 102 & 48.6 \\
\hline 302 & W-15571 & FGS & Core & 28.49250 & -81.95091 & BAY LAKE & 98 & 41.7 \\
\hline 303 & W-15573 & FGS & Core & 28.38751 & -81.85313 & LAKE NELLIE & 111 & 161 \\
\hline 304 & W-15574 & FGS & Core & 28.47846 & -81.90452 & BAY LAKE & 121 & 220 \\
\hline 305 & W-15575 & FGS & Core & 28.43500 & -81.75583 & LAKE NELLIE & 110 & 72.1 \\
\hline 306 & W-15576 & FGS & Core & 28.41556 & -81.81007 & LAKE NELLIE & 112 & 70.9 \\
\hline 307 & W-15577 & FGS & Core & 28.41223 & -81.76702 & LAKE NELLIE & 114 & 96.8 \\
\hline 308 & W-15578 & FGS & Core & 28.42306 & -81.74508 & LAKE LOUISA & 115 & 79.09 \\
\hline 309 & W-15579 & FGS & Core & 28.39695 & -81.74258 & LAKE LOUISA & 119 & 54 \\
\hline 310 & W-15580 & FGS & Core & 28.37890 & -81.70702 & LAKE LOUISA & 134 & 97.8 \\
\hline 311 & W-15581 & FGS & Core & 28.37223 & -81.74285 & LAKE LOUISA SW & 120 & 77 \\
\hline 312 & W-15582 & FGS & Core & 28.37584 & -81.77758 & LAKE NELLIE & 118 & 102.4 \\
\hline 313 & W-15593 & FGS & Core & 28.47806 & -81.97619 & BAY LAKE & 97 & 40.1 \\
\hline 314 & W-15594 & FGS & Core & 28.43806 & -81.98897 & BAY LAKE & 95 & 24 \\
\hline 315 & W-15595 & FGS & Core & 28.40862 & -81.99924 & BAY LAKE & 92 & 21.2 \\
\hline 316 & W-15597 & FGS & Core & 28.31056 & -81.89165 & ROCK RIDGE & 109 & 37 \\
\hline 317 & W-15598 & FGS & Core & 28.30922 & -81.93195 & ROCK RIDGE & 105 & 21 \\
\hline 318 & W-15599 & FGS & Core & 28.25862 & -81.95814 & ROCK RIDGE & 109 & 157 \\
\hline 319 & W-15601 & FGS & Core & 28.30557 & -81.86702 & POYNER & 115 & 82 \\
\hline 320 & W-15602 & FGS & Core & 28.30382 & -81.78040 & POYNER & 130 & 77 \\
\hline 321 & W-15605 & FGS & Core & 28.27501 & -81.77202 & POYNER & 131 & 111 \\
\hline 322 & W-15606 & FGS & Core & 28.30568 & -81.73418 & LAKE LOUISA SW & 124 & 82 \\
\hline 323 & W-15608 & FGS & Core & 28.25461 & -81.67048 & LAKE LOUISA SW & 124 & 87 \\
\hline 324 & W-15609 & FGS & Core & 28.31668 & -81.70230 & LAKE LOUISA SW & 119 & 119 \\
\hline 325 & W-15611 & FGS & Core & 28.34156 & -81.72211 & LAKE LOUISA SW & 119 & 104 \\
\hline 326 & W-15612 & FGS & Core & 28.23556 & -81.75763 & POLK CITY & 132 & 92 \\
\hline 327 & W-15613 & FGS & Core & 28.21806 & -81.72194 & GUM LAKE & 135 & 84 \\
\hline 328 & W-15614 & FGS & Core & 28.32251 & -81.89896 & ROCK RIDGE & 103 & 44 \\
\hline 329 & W-15616 & FGS & Core & 28.35390 & -81.96564 & ROCK RIDGE & 98 & 35.1 \\
\hline 330 & W-15617 & FGS & Core & 28.32501 & -81.99814 & ROCK RIDGE & 93 & 54 \\
\hline 331 & W-15619 & FGS & Core & 28.36806 & -81.98230 & ROCK RIDGE & 95 & 32.5 \\
\hline 332 & W-15620 & FGS & Core & 28.38445 & -81.96480 & BAY LAKE & 97 & 46 \\
\hline 333 & W-15622 & FGS & Core & 28.41223 & -81.96397 & BAY LAKE & 96 & 38 \\
\hline 334 & W-15623 & FGS & Core & 28.45556 & -81.99452 & BAY LAKE & 96 & 21 \\
\hline 335 & W-15624 & FGS & Core & 28.47139 & -81.99675 & BAY LAKE & 93 & 52.5 \\
\hline 336 & W-15650 & FGS & Cuttings & 28.31056 & -81.91119 & ROCK RIDGE & 109 & 385 \\
\hline 337 & W-15726 & FGS & Cuttings & 28.46875 & -81.48490 & LAKE JESSAMINE & 160 & 4960 \\
\hline 338 & W-15745 & FGS & Cuttings & 28.46021 & -81.49219 & LAKE JESSAMINE & 156 & 418 \\
\hline 339 & W-15837 & FGS & Cuttings & 28.49916 & -81.59066 & WINDERMERE & 105 & 430 \\
\hline
\end{tabular}


FLORIDA GEOLOGICAL SURVEY

\begin{tabular}{|c|c|c|c|c|c|c|c|c|}
\hline $\begin{array}{l}\text { Map } \\
\text { ID }\end{array}$ & $\begin{array}{c}\text { Well } \\
\text { Label }\end{array}$ & $\begin{array}{c}\text { Data } \\
\text { Source }\end{array}$ & $\begin{array}{c}\text { Sample } \\
\text { Type }\end{array}$ & Latitude & Longitude & 24K Quad & $\begin{array}{c}\text { Elevation } \\
\text { (ft.) }\end{array}$ & $\begin{array}{c}\text { Total } \\
\text { Depth (ft.) }\end{array}$ \\
\hline 340 & W-15967 & FGS & Cuttings & 28.15096 & -81.44798 & LAKE TOHOPEKALIGA & 65 & 1380 \\
\hline 341 & W-16034 & FGS & Cuttings & 28.25612 & -81.37969 & KISSIMMEE & 60 & 460 \\
\hline 342 & W-16189 & FGS & Cuttings & 28.25167 & -81.32972 & SAINT CLOUD NORTH & 57 & 412 \\
\hline 343 & W-16229 & FGS & Cuttings & 28.45906 & -81.15293 & NARCOOSSEE NW & 70 & 450 \\
\hline 344 & W-16262 & FGS & Cuttings & 28.06272 & -81.05937 & HOLOPAW SE & 74 & 950 \\
\hline 345 & W-16325 & FGS & Cuttings & 28.06267 & -81.01027 & HOLOPAW SE & 65 & 790 \\
\hline 346 & W-16402 & FGS & Cuttings & 28.02247 & -81.58709 & DUNDEE & 156 & 205 \\
\hline 347 & W-16416 & FGS & Cuttings & 28.04861 & -81.59500 & DUNDEE & 155 & 80 \\
\hline 348 & W-16532 & FGS & Cuttings & 28.15494 & -81.45189 & LAKE TOHOPEKALIGA & 66 & 500 \\
\hline 349 & W-16541 & FGS & Cuttings & 28.20819 & -81.43311 & LAKE TOHOPEKALIGA & 67 & 420 \\
\hline 350 & W-16952 & FGS & Cuttings & 28.17306 & -81.13167 & ASHTON & 71 & 500 \\
\hline 351 & W-16954 & FGS & Cuttings & 28.25196 & -81.32924 & SAINT CLOUD NORTH & 58 & 460 \\
\hline 352 & W-16955 & FGS & Cuttings & 28.02835 & -81.19062 & HOLOPAW SW & 77 & 670 \\
\hline 353 & W-17017 & FGS & Cuttings & 28.28250 & -81.35064 & SAINT CLOUD NORTH & 62 & 390 \\
\hline 354 & W-17019 & FGS & Cuttings & 28.16586 & -81.43147 & LAKE TOHOPEKALIGA & 62 & 480 \\
\hline 355 & W-17021 & FGS & Cuttings & 28.26667 & -81.56586 & INTERCESSION CITY & 89 & 340 \\
\hline 356 & W-17207 & FGS & Cuttings & 28.11528 & -81.00806 & HOLOPAW SE & 48 & 780 \\
\hline 357 & W-17300 & FGS & Cuttings & 28.42528 & -81.11534 & NARCOOSSEE NE & 64 & 1250 \\
\hline 358 & W-17427 & FGS & Cuttings & 28.31111 & -81.46583 & KISSIMMEE & 74 & 230 \\
\hline 359 & W-17428 & FGS & Cuttings & 28.30547 & -81.34425 & SAINT CLOUD NORTH & 80 & 220 \\
\hline 360 & W-17430 & FGS & Cuttings & 28.25098 & -81.47119 & KISSIMMEE & 75 & 330 \\
\hline 361 & W-17455 & FGS & Core & 28.07139 & -81.95556 & LAKELAND & 173 & 57 \\
\hline 362 & W-17480 & FGS & Cuttings & 28.42112 & -81.27368 & PINE CASTLE & 86 & 2460 \\
\hline 363 & W-17575 & FGS & Core & 28.18056 & -81.59389 & DAVENPORT & 113 & 57 \\
\hline 364 & W-17576 & FGS & Core & 28.19167 & -81.68667 & GUM LAKE & 129 & 56 \\
\hline 365 & W-17588 & FGS & Cuttings & 28.40334 & -81.35340 & PINE CASTLE & 84 & 2000 \\
\hline 366 & W-17855 & FGS & Cuttings & 28.39389 & -81.01722 & NARCOOSSEE NE & 66 & 315 \\
\hline 367 & W-17871 & FGS & Cuttings & 28.44278 & -81.43361 & LAKE JESSAMINE & 80 & 1350 \\
\hline 368 & W-17934 & FGS & Cuttings & 28.13750 & -81.03722 & HOLOPAW & 69 & 24 \\
\hline 369 & W-18003 & FGS & Cuttings & 28.46083 & -81.09583 & NARCOOSSEE NE & 64 & 56 \\
\hline 370 & W-18445 & FGS & Cuttings & 28.37889 & -81.58778 & WINDERMERE & 89 & 2100 \\
\hline 371 & W-18446 & FGS & Cuttings & 28.47167 & -81.53472 & WINDERMERE & 107 & 650 \\
\hline 372 & W-18465 & FGS & Cuttings & 28.25222 & -81.32861 & SAINT CLOUD NORTH & 58 & 1500 \\
\hline 373 & W-18500 & FGS & Cuttings & 28.47694 & -81.11222 & NARCOOSSEE NE & 50 & 22 \\
\hline 374 & W-18691 & FGS & Cuttings & 28.17183 & -81.90133 & PROVIDENCE & 132 & 151 \\
\hline 375 & W-18748 & FGS & Core & 28.15664 & -81.56481 & DAVENPORT & 90 & 408 \\
\hline 376 & W-18968 & FGS & Core & 28.38719 & -81.98358 & BAY LAKE & 93 & 5 \\
\hline 377 & W-19447 & FGS & Core & 28.10881 & -81.83736 & AUBURNDALE & 149 & 2810 \\
\hline
\end{tabular}

